\title{
Metabolic Spectrum of Liver Failure in Type 2 Diabetes and Obesity: From NAFLD to NASH to HCC
}

\author{
Hyunmi Kim ${ }^{1,2,+} \mathbb{1}$, Da Som Lee ${ }^{1,+}$, Tae Hyeon An ${ }^{1,2,+} \mathbb{C}$, Hyun-Ju Park ${ }^{1,2}$, Won Kon Kim ${ }^{1,2}$, \\ Kwang-Hee Bae ${ }^{1,2, *(D)}$ and Kyoung-Jin Oh ${ }^{1,2, *(D)}$ \\ 1 Metabolic Regulation Research Center, Korea Research Institute of Bioscience and Biotechnology (KRIBB), 125 \\ Gwahak-ro, Yuseong-gu, Daejeon 34141, Korea; khm7607@kribb.re.kr (H.K.); dasom89@kribb.re.kr (D.S.L.); \\ anth0291@kribb.re.kr (T.H.A.); h18509@kribb.re.kr (H.-J.P.); wkkim@kribb.re.kr (W.K.K.) \\ 2 Department of Functional Genomics, KRIBB School of Bioscience, Korea University of Science and \\ Technology (UST), 217 Gajeong-ro, Yuseong-gu, Daejeon 34141, Korea \\ * $\quad$ Correspondence: khbae@kribb.re.kr (K.-H.B.); kjoh80@kribb.re.kr (K.-J.O.); Tel.: +82-42-860-4268 (K.-H.B.); \\ $+82-42-879-8265$ (K.-J.O.) \\ + These authors contributed equally to this work.
}

Citation: Kim, H.; Lee, D.S.; An, T.H.; Park, H.-J.; Kim, W.K.; Bae, K.-H.; Oh, K.-J. Metabolic Spectrum of Liver Failure in Type 2 Diabetes and Obesity: From NAFLD to NASH to HCC. Int. J. Mol. Sci. 2021, 22, 4495. https://doi.org/10.3390/ijms22094495

Academic Editors: Montserrat Esteve and Maria del Mar Romeno

Received: 2 April 2021

Accepted: 23 April 2021

Published: 26 April 2021

Publisher's Note: MDPI stays neutral with regard to jurisdictional claims in published maps and institutional affiliations.

Copyright: (c) 2021 by the authors. Licensee MDPI, Basel, Switzerland. This article is an open access article distributed under the terms and conditions of the Creative Commons Attribution (CC BY) license (https:// creativecommons.org/licenses/by/ $4.0 /)$.

\begin{abstract}
Liver disease is the spectrum of liver damage ranging from simple steatosis called as nonalcoholic fatty liver disease (NAFLD) to hepatocellular carcinoma (HCC). Clinically, NAFLD and type 2 diabetes coexist. Type 2 diabetes contributes to biological processes driving the severity of NAFLD, the primary cause for development of chronic liver diseases. In the last 20 years, the rate of non-viral NAFLD/NASH-derived HCC has been increasing rapidly. As there are currently no suitable drugs for treatment of NAFLD and NASH, a class of thiazolidinediones (TZDs) drugs for the treatment of type 2 diabetes is sometimes used to improve liver failure despite the risk of side effects. Therefore, diagnosis, prevention, and treatment of the development and progression of NAFLD and NASH are important issues. In this review, we will discuss the pathogenesis of NAFLD/NASH and NAFLD/NASH-derived HCC and the current promising pharmacological therapies of NAFLD/NASH. Further, we will provide insights into "adipose-derived adipokines" and "liver-derived hepatokines" as diagnostic and therapeutic targets from NAFLD to HCC.
\end{abstract}

Keywords: non-alcholic fatty liver disease (NAFLD); non-alcoholic steatohepatitis (NASH); hepatocellular carcinoma (HCC); type 2 diabetes; obesity; adipokines; hepatokines

\section{Introduction}

Type 2 diabetes is the main public health problem in terms of global epidemic and pandemic diseases [1,2]. It is closely related with the worldwide epidemic of obesity, and approximately $75 \%$ of type 2 diabetes is related with obesity [3,4]. The relationship between type 2 diabetes and obesity is further explained by the descriptive term of "Diabesity" [5]. Actually, the modern sedentary lifestyle contributes to weight gain by promoting excessive food intake and even adding physical inactivity $[6,7]$. For that reason, chronic metabolic diseases such as type 2 diabetes and obesity have been increasing globally.

Together with obesity and type 2 diabetes, non-alcoholic fatty liver (NAFLD) is the most common liver disease, and is observed in approximately $30 \%$ of the general population [8-10]. NAFLD is characterized by hepatic triglyceride (TG) accumulation and insulin resistance [11,12]. It is the hepatic manifestation of metabolic syndrome and is a spectrum of conditions ranging from benign hepatic steatosis to non-alcoholic steatohepatitis (NASH) [13]. That is, it is broadly categorized into non-alcoholic fatty liver (NAFL) and NASH [14]. NAFL is marked by isolated steatosis, and NASH is characterized by steatosis, lobular inflammation (inflammatory cell infiltration), and hepatocellular ballooning in the presence or absence of fibrosis [15]. NASH, the more aggressive form of NAFLD, could develop into progressive fibrosis, and is directly associated with the 
risk of developing hepatocellular carcinoma (HCC), which could be a major cause of morbidity and mortality induced from liver failure (Figure 1) [8]. The prevalence of NASH is approximately $\sim 30 \%$ for patients with NAFLD [16-19]. Approximately $20 \%$ of NASH patients with fibrosis progress to cirrhosis [20]. Liver cirrhosis is present in only $50 \%$ of patients with NAFLD-related HCC [21,22]. The incidence of NAFLD-related HCC without cirrhosis is approximately $8 \%$ of all HCC cases $[23,24]$. The incidence rate for HCC in NAFLD/NASH with cirrhosis ranges from $2 \%$ to $13 \%$ (Figure 1) $[25,26]$.

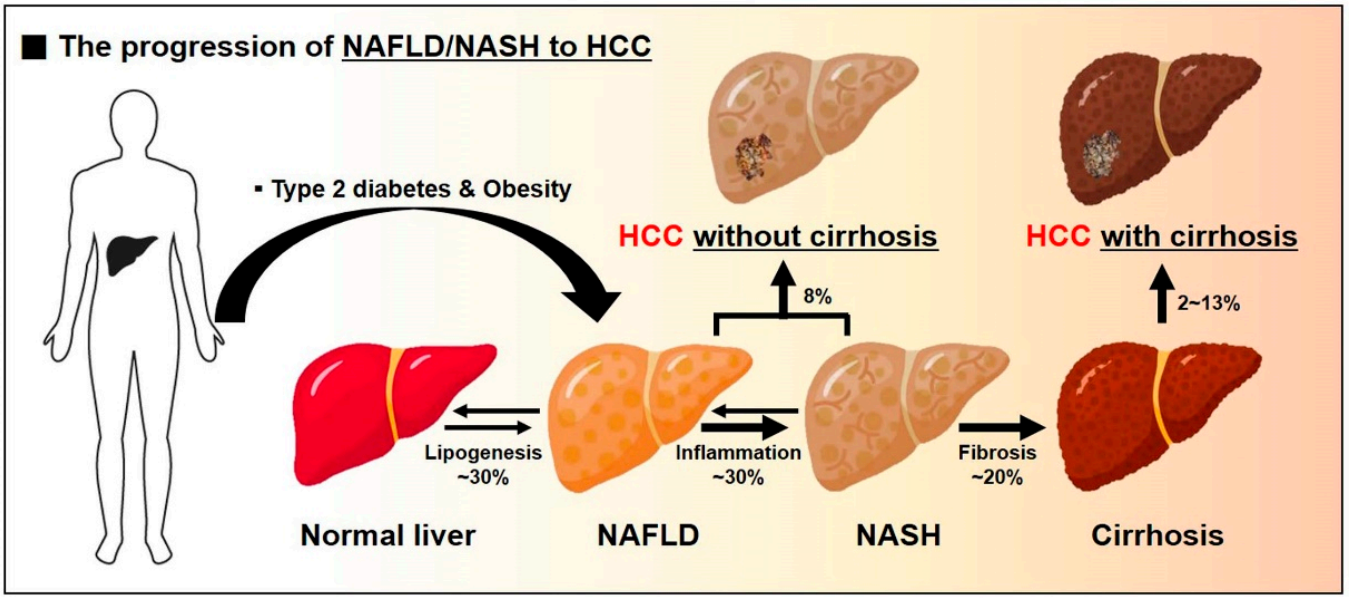

Figure 1. Type 2 diabetes and obesity aggravate the progression of NAFLD/NASH to HCC. Clinically, type 2 diabetes coexists with NAFLD, and it aggravates NAFLD to more severe forms of NASH, hepatocirrhosis, and HCC, leading to a metabolically worse phenotype.

Clinically, NAFLD coexists with type 2 diabetes and obesity, and it exerts a synergistic effect, leading to more severe liver failures [27]. The prevalence rate of NAFLD is estimated to be approximately $75 \%$ in patients with type 2 diabetes and about $90 \%$ in the obese population, which show the strong relationship of NAFLD with type 2 diabetes and obesity [28-31]. NAFLD plays an important role in increases of the incidence of type 2 diabetes and its complications [28]. Type 2 diabetes also exacerbates NAFLD to more severe forms of NASH, fibrosis, and HCC (Figure 1) [30,32,33].

$\mathrm{HCC}$ is one of the most aggressive growing cancers [34,35]. Previously, hepatitis C virus (HCV) was thought to be the leading cause of HCC [36-38], but recent reports that showed up to $50 \%$ of newly diagnosed HCC patients are non-viral HCC [39,40], Therefore, NAFLD/NASH-derived HCC has been highlighted. The etiology of NAFLD/NASHderived HCC is very complex and is related with various mechanisms such as cellular plasticity, inflammation, apoptosis, cell cycle, and cell death [41,42]. It is not easy to treat and improve HCC. Therefore, NAFLD/NASH treatment is required for prevention of irreversible chronic liver diseases such as cirrhosis and HCC. Unfortunately, there are no FDA-approved drugs and treatment methods yet.

In this review, we will discuss the pathogenesis of NAFLD/NASH and NAFLD/ NASH-derived HCC and the current promising pharmacological therapies of NAFLD/ NASH. Further, the initiation and progression of NAFLD can be affected by organokines secreted from metabolic organs under metabolic disturbance such as type 2 diabetes and obesity [43-45]. Therefore, we will focus on organokines that are secreted by the adipose tissues and liver, which are critical organs for the regulation of lipid metabolism. We will provide new insights into "adipokines" and "hepatokines" that can be potential diagnostic and therapeutic targets in NAFLD/NASH and NAFLD/NASH-derived HCC. They are thought to be able to be biological markers that can predict NAFLD severity from NAFLD to HCC. 


\section{Non-Alcoholic Fatty Liver Disease (NAFLD) and Non-Alcoholic} Steatohepatitis (NASH)

\subsection{Pathogenesis of NAFLD and NASH}

\subsubsection{An Imbalance in Fatty Acid (FA) Metabolism}

NAFLD is the most common etiology of chronic liver diseases. NAFLD results from excessive triglyceride (TG) accumulation in the liver [11,12]. Therefore, the balance between fatty acid (FA) input and FA output is critical [46,47]. That is, NAFLD develops when the amount of "exogenous FA uptake (dietary intake and adipose tissue lipolysis)" and "endogenous FA synthesis (DNL: de novo lipogenesis)" in the liver is greater than "the release of FAs (FA oxidation, lipolysis, and FA secretion in very low density lipoprotein (VLDL)-TG)" from the liver (Figure 2).

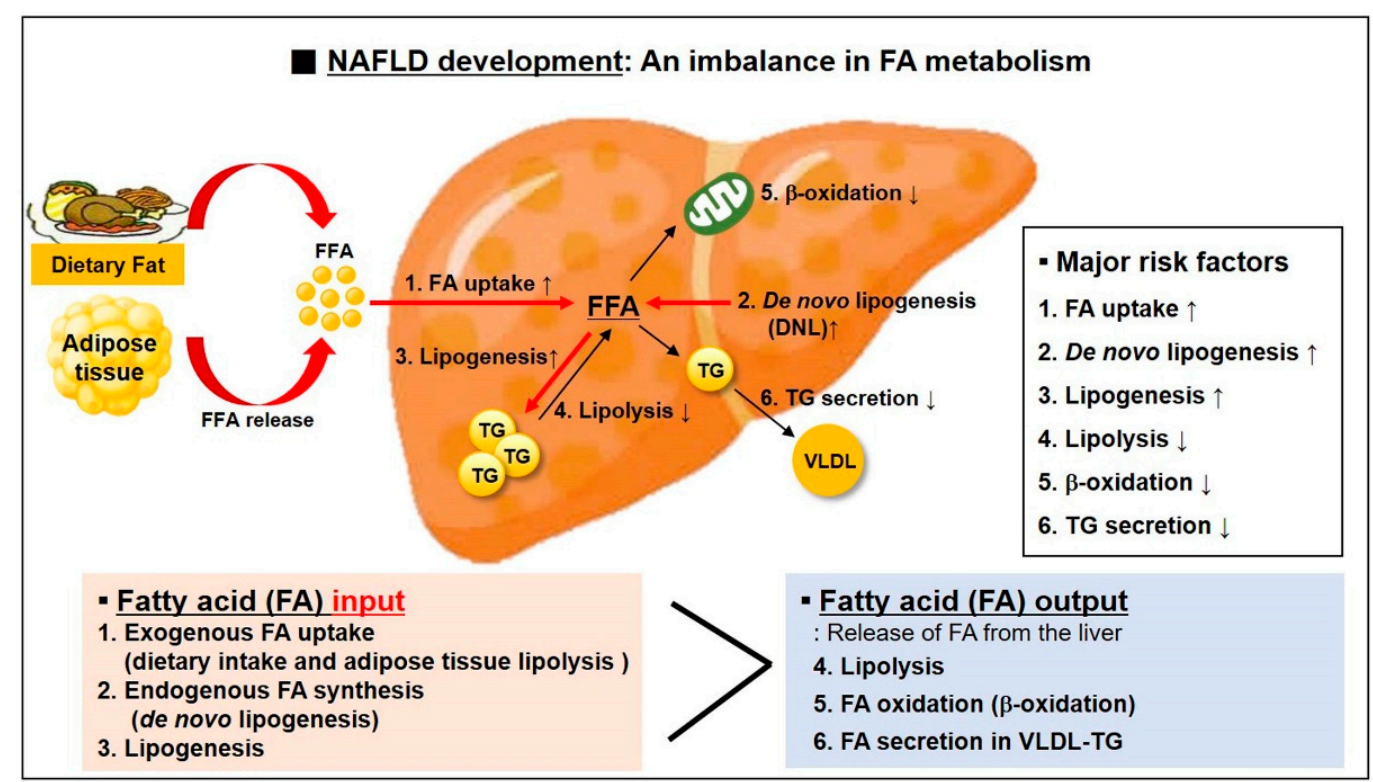

Figure 2. NAFLD development is caused by an imbalance in the intrahepatocellular fatty acid (FA) metabolism. Hepatic TG accumulation is promoted when the FA input is greater than the FA output in the liver. The greater part of FA taken up by liver is mainly derived from the lipolysis of subcutaneous adipose tissue TG. Another major source of FA in the liver is derived from de novo lipogenesis that converts excess glucose into FAs. On the other hand, the consumption of FA is possible through the signaling pathway involved in lipolysis, $\beta$-oxidation, and TG secretion $(\rightarrow$ : signaling pathways related with TG accumulation by FA, $\rightarrow$ : signaling pathways related with the consumption of FA).

The release of FAs from adipose tissue and the efficiency of FA uptake by liver are increased in approximately 59\% of patients with NAFLD [48]. Hepatic FA uptake depends on plasma FA concentration and on hepatocellular capacity for FA uptake that is determined by the number and activity of specialized FA transporter and carrier proteins such as FA translocase (FAT/CD36), FA transport polypeptide (FATP), and FA binding protein (FABP) $[49,50]$. For example, hepatic expression of fatty acid translocase CD36 is markedly increased in subjects with NAFLD, and hepatic expression of FABP-4 and FABP-5 is closely associated with intrahepatic TG accumulation.

In approximately $26 \%$ of patients with NAFLD, the way to provides FA pool in liver is de novo lipogenesis (DNL) [51]. DNL is the metabolic process that synthesizes new FAs from excess glucose [52,53]. It is an important contributor toward hepatic lipid accumulation in the pathogenesis of NAFLD [52,53]. The effects result from activation of two transcription factors, sterol regulatory element binding protein-1c (SREBP-1c) and carbohydrate responsive element binding protein (ChREBP), boosted by insulin and glucose responses to dietary carbohydrates $[54,55]$. They play a synergistically important role in 
the coordinated regulation of hepatic DNL. In the remaining 15\% of patients with NAFLD, FA pool is derived from dietary TG, which is associated with chylomicrons [48].

The most acceptable theory in the pathogenesis of NAFLD is the "two-hit" hypothesis [56]. The first hit is "insulin resistance" caused by excessive FA flux into the liver. The second hit is "inflammation", associated with gut-derived endotoxin, oxidative stress, and mitochondria dysfunction. It is closely related with NAFLD progression toward NASH.

\subsubsection{Endotoxin Behavior}

NALFD and other insulin resistance-related diseases are associated with activation of innate immune system, leading to chronic inflammation [57]. Recently, gut-derived endotoxins, such as lipopolysaccharide (LPS), have been proposed to have a critical role in liver inflammation as well as progression of chronic liver diseases [58]. Under normal conditions, endotoxin can be absorbed from the intestinal lumen into the portal vein system, and the absorbed endotoxin will be rapidly removed in the hepatic reticuloendothelial system, particularly Kupffer cells [59,60]. However, obesity, type 2 diabetes, and other nutrition and environmental factors can alter intestinal permeability for bacterial overgrowth and the resulting leaky mucosal barrier allows bacterial translocation, implicating the release of gut-derived endotoxin into the systemic circulation $[61,62]$. The invasive pathogens and harmful byproducts influence hepatic lipid accumulation and exacerbate pro-inflammatory and fibrotic processes [60].

Recently, the role of LPS from gut microbiota in the development of NAFLD and NASH has been attracting attention [63,64]. Circulating LPS levels, small intestinal permeability, and bacterial overgrowth are increased in patients with NALFD, and these factors are associated with the severity of hepatic steatosis $[63,65,66]$. Livers that directly receives blood from the portal vein are the main target of LPS, also known as endotoxin, and LPS-TLR4 is one of the critical pathways for NAFLD development. In mouse models, LPS infusion triggers hepatic steatosis and hepatic insulin resistance, as well as hepatic weight gain [67]. LPS exacerbates liver injury in mice fed a methionine-choline-deficient diet [68]. The LPS-binding protein (LBP)-CD14 complex activates Toll-like recpeotr4 (TLR4), which is an essential inflammatory cascade in the progression of NAFLD [69,70]. Loss of LBP attenuates inflammation-mediated liver damage [71]. TLR4 can activate NF-kB and release pro-inflammatory cytokines such as interleukin- $1 \beta$ (IL- $1 \beta)$, tumor necrosis factor- $\alpha$ (TNF$\alpha$ ), and IL-6 [72]. It can also recognize damage-associated molecular patterns (DAMPs) that are released from damaged cells, and mediates FA-induced inflammation [57,73]. As pharmacological therapies in NAFLD and NASH targeting the microbiome, there are IMM-24e (anti-LPS antibody), solithromycin (next-generation macrolide antbiotic), and TLR4 antagonist [74].

\subsubsection{Oxidative Stress}

Chronic oxidative stress is one of the key mechanisms leading to liver injury in NAFLD. Oxidative stress is a general event that occur in NAFLD and NASH as result of excessive production of reactive oxygen species (ROS) [75,76]. ROS and lipid peroxidation can explain most of histological features of NAFLD and NASH [77,78]. In patients with hepatic steatosis, mitochondrial ROS oxidizes hepatic fat deposits, and ROS-induced expression of Fas-ligand can induce apoptosis $[77,78]$. Peroxidation of and intracellular membranes can directly trigger necrosis and apoptosis [77,78]. The degree of lipid peroxidation is correlated with the severity of steatosis and can explain the association between steatosis severity and the risk of necroinflammation and fibrosis in NASH [79-81]. ROS, which plays a key player in the pathogenesis of NASH, can lead to a self-perpetuating cycle of lipid peroxidation and can further generate ROS [82]. Lipid peroxidation products alter mitochondrial DNA and activate transcription factor nuclear facto-kB (NF-kB) that upregulates TNF $\alpha[83,84]$. Resultingly, it further contributes to impaired mitochondrial respiration and increased ROS formation $[83,84]$. 
Increased mitochondrial $\beta$-oxidation of FFA is an important source of ROS in NAFLD and NASH [85]. Increased FFA flux in hepatic cells during early stages of NAFLD stimulate mitochondrial fatty acid oxidation (FAO), and it reflects an early effort of the liver compensatory mechanisms to inhibit liver fat accumulation and maintain lipid homeostasis [12]. In NAFLD and NASH, mitochondrial FAO is also increased or at least preserved as a compensatory response. The imbalance between mitochondrial FAO and electron transport chain (ETC) will contribute to ROS overproduction by increased electron leakage from the ETC $[12,85,86]$. ROS-induced lipid peroxidation leads to inflammation and hepatic fibrogenesis through the activation of hepatic stellate cells (HSCs) $[87,88]$.

Recently, reliable circulating markers that can reflect oxidative stress in patients with NAFLD have been reported. Urinary 8-iso-prostaglandin F2 $\alpha$ (8-iso-PGF2 $\alpha$ ) is known as a reliable indicator of oxidative stress in vivo [89,90], and soluble NOX2-derived peptide (sNOX2-dp) are also an acceptable marker, which is associated with ROS generation by activation of NOX2, a member of the NADPH oxidase family [91,92]. Elevated levels of urinary 8-iso-PGF2 $\alpha$ and serum soluble NOX2-derived peptide are considered as a reliable indicator of oxidative stress in chronic inflammation and metabolic diseases [93-95]. They also can be used as markers of oxidative stress for prediction of the severity of liver damage in NAFLD [96,97]. LPS is an important outer membrane component of gram-negative bacteria that induces accelerated inflammation and oxidative stress [98,99]. Elevated levels of circulating NOX2 and LPS in NAFLD patients suggest the potential role of gut-derived LPS in systemic NOX2 activation [100]. Further, sNOX2-dp levels are positively related with the histological grading of steatosis, inflammation, ballooning, fibrosis, and NAFLD activity score [100]. Gut-derived LPS can stimulate TLR4, and TLR4-mediated NOXs activation can generate ROS by macrophage infiltration [101]. It can contribute to hepatic steatosis and insulin resistance [101].

However, the variety of metabolic changes occurred in NAFLD are insufficient to be explained only by the "two-hit" hypothesis. Most metabolic disorders such as obesity, type 2 diabetes, metabolic syndrome, and dyslipidemia are the risk factors for NAFLD development. Recently, it has been thought that the development and progression of NAFLD are induced by the "multiple-hits" involving various factors (Figure 3) [102,103]. The "multiplehits" include bioactive molecules secreted from the adipose tissue, nutritional factors, and environmental factors [102].

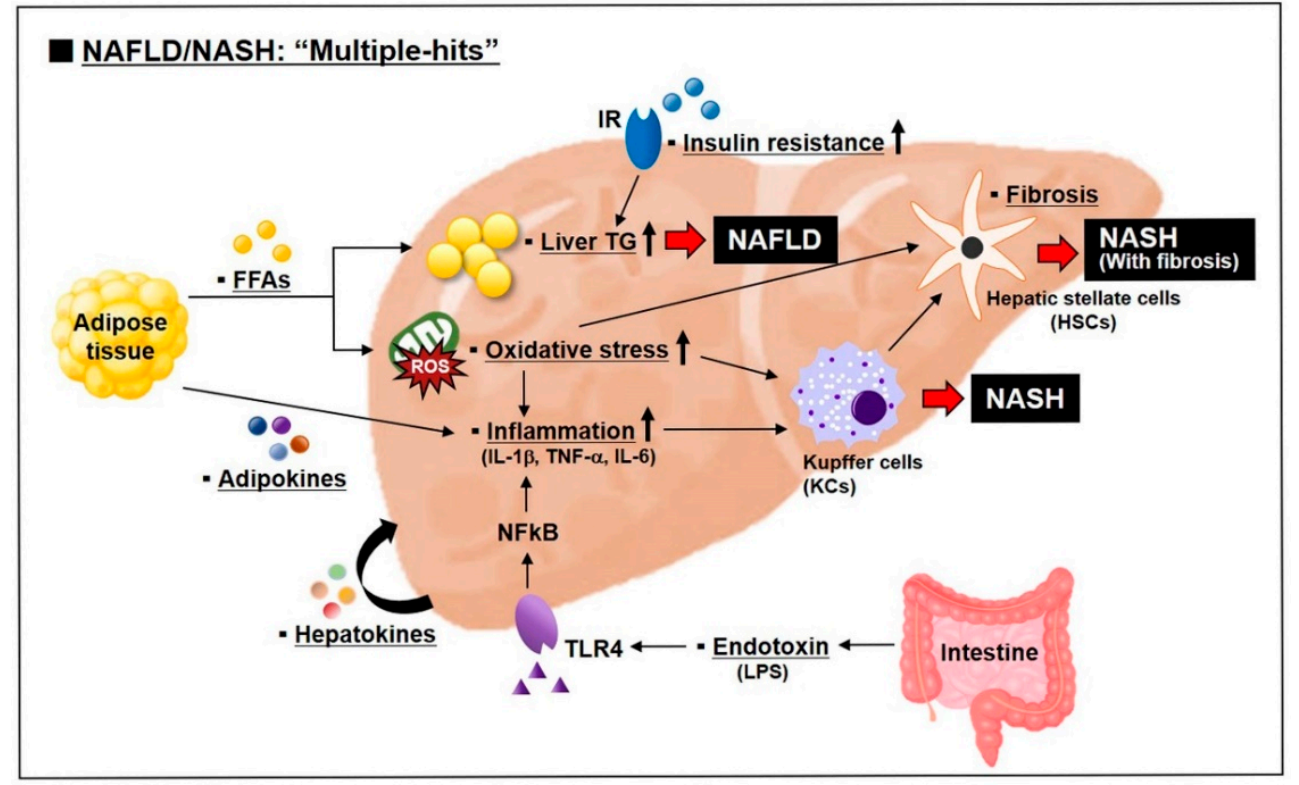

Figure 3. Multiple-hits pathogenesis of NAFLD and NASH. NAFLD begins with hepatic lipid accumulation and insulin resistance, and progresses to NASH with the concert of various factors such as inflammation, endotoxin, organokines (adipokines and hepatokines), and oxidative stress. (*: Factors related with multiple-hits). 


\subsection{Promising Therapies in NAFLD and NASH}

As recently recommended pharmacotherapies, it has been reported that pioglitazone and high dosage vitamin E effectively improve the histology of patients with NASH [104-106]. On the other hand, metformin does not recover liver histology of patients with NAFLD [107,108], and ursodeoxycholic acid (UDCA) does not improve liver histology, inflammation, or fibrosis of patients with NASH [109-111]. Below are some of pharmaco-therapeutic options that are in clinical trials or could be good candidates for NASH treatment (Figure 4). Additionally, the metabolic profile and liver histology-related efficacy of these promising drugs in humans are summarized in Table 1.

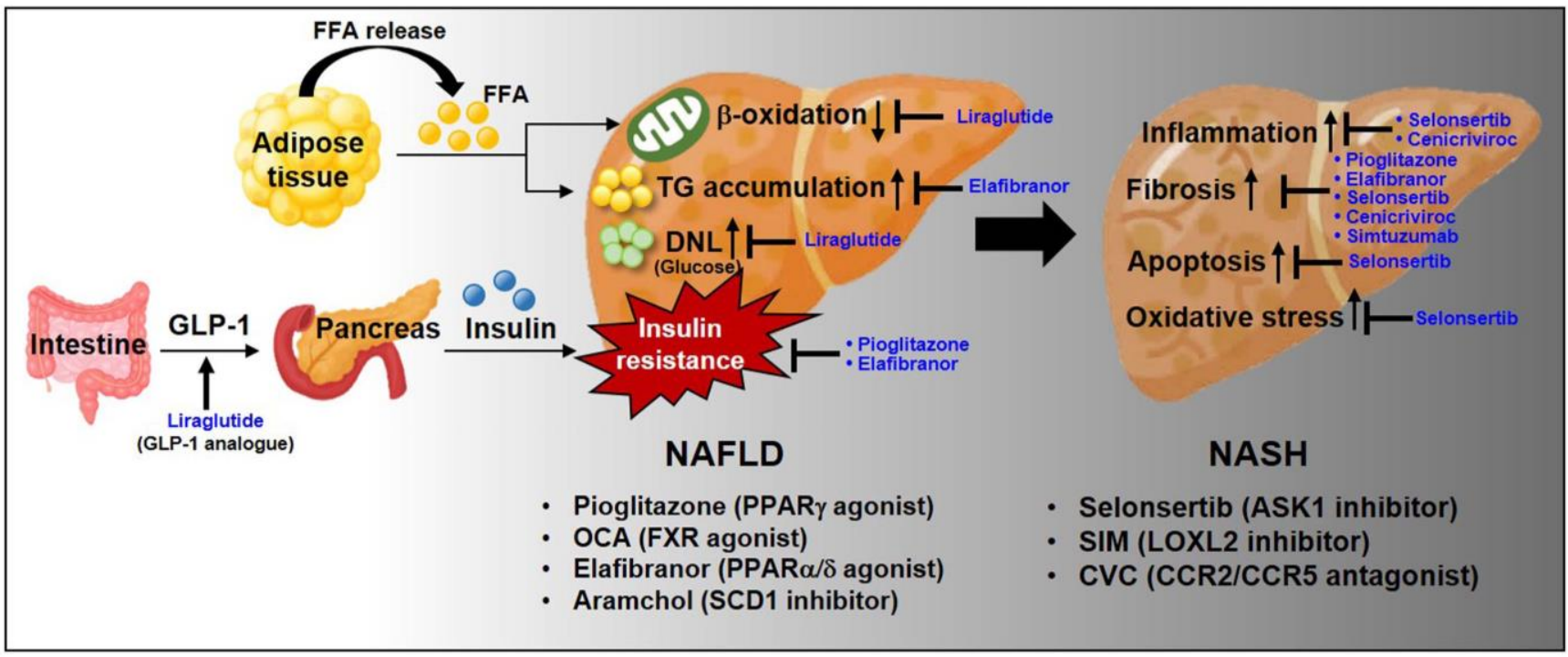

Figure 4. Current therapeutic targets for pharmacological treatment of NAFLD and NASH. There are no FDA-approved medications for patients with NAFLD/NASH so far. Currently, various pharmacological therapeutic candidates are being applied to the clinical trials. The illustration demonstrates the targeted pathway and phenotype for treatment of patients with NAFLD and NASH.

\subsubsection{Pioglitazone}

Pioglitazone is one of the anti-diabetic agents of the thiazolidinediones (TZDs) class used in the management of type 2 diabetes [112]. TZDs is also known as "glitazones". There are two TZDs, rosiglitazone and pioglitazone, which are currently approved by the FDA as monotherapy or combined therapies with metformin and sulfonylureas for managing type 2 diabetes [113]. TZDs, as insulin sensitizers, help regulate glycemia and insulin resistance [113]. The most important advantage of TZD is that it does not cause hypoglycemia with single therapy, and there are no contraindications for patients with renal disease [114].

TZDs regulates metabolic pathways by binding to the nuclear transcription factor peroxisome proliferator-activated receptor gamma (PPAR $\gamma$ ) and modulating target gene expression [115]. The genes play a role in glucose metabolism, FA storage, and adipocyte differentiation [116]. In line with this, PPAR $\gamma$ agonists increase glucose transporter 4 (GLUT4, also known as SLC2A4) expression and translocation, inhibit TNF- $\alpha$, and enhance insulin sensitivity in insulin-sensitive organs $[117,118]$. On the other hand, TZD therapy leads to weight gain as a side effect, because PPAR $\gamma$ receptors are highly expressed in adipocytes [119]. Increases in fat mass are exclusively limited to the subcutaneous adipose depot rather than the visceral spot $[117,120]$. They can be improved by treatment with metformin [121,122].

Recently, it was reported that the PPAR $\gamma$ agonist Pioglitazone has significant effects on NAFLD/NASH patients. In NASH patients, it improves liver fat accumulation and fibrosis $[123,124]$. In NASH patients with type 2 diabetes, it reduces hepatic steatosis, in- 
flammation, and the serum alanine aminotransferase (ALT) and aspartate aminotransferase (AST) levels and improves the liver [125]. In rodent models, it reduces hepatic gluconeogenesis, and improves insulin sensitivity in the liver and other peripheral tissues [126]. It also improves hepatic fibrosis [126].

\subsubsection{Obeticholic acid (OCA, Also Known as INT-747; FXR Agonist)}

OCA is a potent and selective agonist of farnesoid $\mathrm{X}$ receptor (FXR), a nuclear receptor that can regulate hepatic glucose and lipid metabolism, inflammation, and lipoprotein composition as well as bile acid synthesis $[127,128]$. In rodent models, OCA exerts the HSCs and macrophages anti-inflammatory and anti-fibrotic effects $[129,130]$. The transcriptional repressor small or short heterodimer partner (SHP) interacts with liver receptor homolog-1 (LRH-1), a positive regulator of CYP7A1 that encodes the rate-limiting enzyme in the classic bile acid synthesis pathways, and suppresses its transcriptional activity [131]. Exposure of HSCs to FXR ligands increases the transcriptional repressor SHP expression and reduces factors associated with liver fibrosis [130]. It is thought that an FXR-SHP regulatory axis plays an important role in regulating liver fibrosis. OCA-induced FXR activity is 100-fold more potent than human natural FXR agonist, chenodeoxycholic acid (CDCA) [132]. OCA increases insulin sensitivity and reduces markers related with hepatic inflammation and fibrosis in patients with type 2 diabetes and NAFLD [133]. OCA leads to weight loss in patients with NASH, and weight loss caused by OCA is shown to exert additively beneficial effects on serum aminotransferase and liver histology [134]. Additionally, it significantly improves fibrosis in NASH patients [135]. It is one of the most promising drugs for treating NASH and is now in phase 3 clinical trials [136].

\subsubsection{Elafibranor (GFT505; PPAR $\alpha / \delta$ Agonist)}

PPARs are ligand-activated transcription factors of nuclear hormone receptor superfamily [137]. They are expressed in the liver, adipose tissue, skeletal muscle, heart, and kidney, and regulate metabolic pathways including $\beta$-oxidation and gluconeogenesis [136]. There are three nuclear receptor isoforms: PPAR alpha $(\alpha)$, PPAR delta $(\delta)$, and PPAR gamma $(\gamma)$. PPAR $\alpha$ promotes $\beta$-oxidation, reduces TG levels, and increases high-density lipoprotein (HDL) cholesterol [138]. It also inhibits NF-kB-induced inflammatory genes [138]. PPAR $\alpha$ agonist, in forms such as fibric acid derivatives (fibrates), is broadly used for treatment of hypertriglycemia, whereas it has no significant effects on patients with NAFLD [139]. This is considered to be because PPAR $\alpha$ receptors are present in other organs as well as the liver. Similar to PPAR $\alpha$, PPAR $\delta$ increases FA oxidation and additionally reduces activation of macrophages and Kupffer cells because it is present in macrophages [140]. GW501516 is a synthetic PPAR $\delta$-specific agonist [141,142]. GW501516 might be considered as a promising therapy in clinical trials because of its potent efficacy, but it has safety concerns [143].

Elafibranor, also known as GFT505, is a dual PPAR $\alpha / \delta$ agonist [144]. It improves inflammation, apoptosis, and necroptosis in the NASH mouse model [145]. It reduced histopathologically hepatic steatosis and inflammation, and reduced fibrosis severity in both NAFLD/NASH and fibrosis mouse models [146,147]. It tends to reduce body weight, but not liver weight in diet-induced NAFLD/NASH rodent models $[148,149]$. In obese patients, it improves hepatic and peripheral insulin sensitivity [150]. Further, it inhibits proinflammatory (IL-1 $\beta$, TNF- $\alpha$, and F4/80) and profibrotic (transforming growth factor- $\beta$ (TGF- $\beta$ ), tissue inhibitor of metalloproteinase 2 , collagen type I, alpha 1 , and collagen type I, alpha 2) markers in obese patients [151]. In addition, it decreases liver dysfunction markers such as ALT and alkaline phosphatase (ALP) [146,151]. It did not cause weight gain [144,152]. It is currently being evaluated in a pivotal phase 3 clinical trials in NASH patients [136]. 


\subsubsection{Arachidyl Amido Cholanoic Acid (Aramchol)}

Aramchol is the liver targeted, oral stearoyl-CoA desaturase 1 (SCD1) inhibitor [153]. It is a novel fatty acid bile acid conjugate (FABACs) [153]. In rodents, aramchol affects liver fat metabolism by reducing FA synthesis and increasing $\beta$-oxidation $[154,155]$. Furthermore, aramchol activates cholesterol efflux by stimulating the ATP-binding cassette transporter A1 (ABCA1) [156]. In addition, it reduces inflammation and fibrosis in methionine and choline deficient (MCD) fed mice [153]. Additionally, it improves steatohepatitis and fibrosis by decreasing SCD1 levels and by regulating the transsulfuration pathway, leading to a rise in glutathione (GSH) levels and the glutathione disulfide (GSSG)/GSH redox couple to properly balance the redox environment [153]. Weight loss by aramchol treatment is known to stabilize within 1 week [153].

In in a phase 2 trial of patients with NAFLD, aramchol reduces the liver fat content and improves liver histology [157]. There was no significant toxicity as determined by the circulating ALT, AST, and alkaline phosphatase levels [157]. Because it targets both the general characteristics of NASH (excessive liver fat contents, lipotoxicity, and oxidative stress) and fibrosis [153], aramchol is currently being developed for the treatment of NASH and fibrosis. It is known that there were no significant changes in the body weight of NASH patients. Phase 3 clinical trials in patients with NASH and fibrosis were initiated in 2019 and are ongoing.

\subsubsection{Liraglutide (GLP-1R Agonist)}

Glucagon-like peptide-1 receptor (GLP-1R) agonists are well established as an effective medication showing promising anti-diabetic effects in both animal models and patients with type 2 diabetes [158-160]. GLP-1 is a incretin hormone that is secreted from L-cells in the distal ileum and colon [161]. It stimulates the pancreas, leading to insulin biosynthesis and insulin secretion, and reduces glucagon production [162,163]. Endogenous GLP-1 is degraded within a few minutes by the dipeptidyl peptidase-4 (DPP-4) enzyme, but liraglutide works for a long time, with a half-life of $13 \mathrm{~h}$ [164].

Exenatide, a synthetic exendin- 4 , was the first GLP-1R agonist approved by the FDA in 2005 for the treatment of type 2 diabetes, as monotherapy or as add-on treatment to metformin and/or sulfonylurea where control was inadequate [165].

Liraglutide is the second GLP-1R agonist to be licensed the FDA in 2010 for the treatment of type 2 diabetes. It is also received FDA approval in 2020 as a treatment for obesity patients, based on its lasting weight loss benefits [166,167]. It has cardiovascular safety in treatment for weight management [168]. Liraglutide-induced anorexia is also related with glutamatergic POMC neuron, leading to weight loss [169]. In patients with NAFLD and NASH, it decreases liver fat contents and improves histological resolution and serum liver enzyme levels without worsening fibrosis $[170,171]$. It is thought that the effect of liraglutide on weight loss and reduced cardiovascular risk is critical for treatment of NAFLD because the development of NAFLD is based on lipotoxicity and insulin resistance $[171,172]$. As studies associated with NAFLD and NASH in rodents showed, liraglutide protects pancreatic $\beta$-cells from apoptosis through AKT-mediated survival signaling [173]. It improves insulin sensitivity by activating AMP-activated protein kinase (AMPK) and reduces liver steatosis by modulating lipid transport, $\beta$-oxidation, DNL, and autophagy [174-176].

\subsubsection{Selonsertib (ASK1 Inhibitor)}

Ballooned hepatocytes, implicating activation of the apoptotic pathway, are a hall marker of NASH and fibrosis progression [177,178]. Selonsertib is a first-in-class inhibitor of the apoptosis signal regulating kinase 1(ASK1) [179]. It inhibits the phosphorylation and activation of ASK1 by binding to the catalytic kinase domain of ASK1. Recently, it has proposed as therapeutic potential for fibrotic diseases. In mouse models, ASK1, a serine/threonine signaling kinase, causes phosphorylation of p38 mitogen-activated kinase and c-Jun N-terminal kinase (JNK), leading to activation of stress response pathways that 
aggravate hepatic inflammation, apoptosis, and fibrosis [180-182]. In mouse models of $\mathrm{NASH}$, it significantly improves not only liver steatosis and fibrosis associated with NASH but also cholesterol, bile acid, and lipid metabolism [180]. In phase 2 clinical trials of patients with NASH and stage 2-3 fibrosis, it has been shown to prevent inflammation, fibrosis, excessive apoptosis, and progression to cirrhosis [183]. On the other hand, phase 3 clinical trials of patients with NASH and advanced fibrosis were found to improve liver histology, but did not affect fibrosis regression $[184,185]$

\subsubsection{Simtuzumab (SIM, G6624)}

SIM is a monoclonal antibody targeting the lysyl oxidase-like 2 (LOXL2) enzyme that catalyzes the crosslinkage of collagen and elastin, leading to remodeling of the extracellular matrix [186,187]. SIM binds to LOXL2 and inhibits its enzymatic activity [188]. As a result, it inhibits synthesis of growth factors including connective tissue growth factor (CTGF/CCN2) and TGF $\beta 1$, and reduces liver fibrosis [189]. In a mouse model with advanced fibrosis, SIM has an additive effect in combination with ASK1 inhibitor [183]. However, in phase $2 \mathrm{~b}$ clinical trials of subjects with advanced fibrosis induced by NASH, it was no effect on improving fibrosis and cirrhosis confirmed by hepatic collagen content [190].

\subsubsection{Cenicriviroc (CVC; Dual CCR2/CCR5 Antagonist)}

Liver inflammation is closely associated with chemokines that regulate activities and migration of hepatocytes and immune cells [191]. The C-C chemokine receptors CCR2 and CCR5 with their respective ligands (CCL2 and CLL3-5) are associated with the pathogenesis of liver inflammation and fibrosis for the development of NAFLD and NASH [191-193]. CCR2 and its ligand CCL2 enhances hepatic steatosis, macrophage accumulation, inflammation, and fibrosis [191]. Activated HSCs, a contributor for fibrosis, secretes CCL5. CCL5 exerts profibrotic activity in hepatocytes via its receptors CCR5 and induces lipid accumulation and pro-inflammatory factors [192].

CVC is a novel and potent antagonist of CCR2 and CCR5 that is currently in clinical development for treatment of liver fibrosis in patients with NASH [194,195]. CVC reduces levels of inflammation markers including IL- $1 \beta$ and IL- 6 and exerts anti-fibrotic activities [194,195]. It received Fast Track designation by the FDA in 2015 as a promising therapy for NASH and liver fibrosis. In the phase $2 \mathrm{~b}$ study of subjects with NASH and stage 2-3 fibrosis, CVC has shown improvement in liver fibrosis without worsening NASH [196]. Currently, phase 3 clinical trials are ongoing to evaluate and confirm the efficacy and safety of CVC for the treatment of liver fibrosis in patients with NASH [197].

\subsection{Diagnostic and Therapeutic Targets in NAFLD and NASH: Adipokines}

Recently, it has been believed that NAFLD and NASH are caused by the multiple factors [102,103]. Among them, we will focus on adipokines secreted from adipose tissues that provide FA as the major source for NAFLD development [48]. Several adipokines are involved in the pathogenesis and progression of NAFLD [198]. Leptin, resistin, and visfatin play a role in NAFLD development and progression to NASH [199-204]. On the other hand, adiponectin, irisin, and ghrelin exert beneficial effects on NAFLD and NASH [205-211]. Pharmacological agents that affect liver histology and pathophysiology could be influential in theses adipokine levels. It suggests that adipokines can be attractive targets for treatment and can be biomarkers for prediction of NAFLD severity (Figure 5). Adipokines can also play an active role in the development of HCC.

Table 1. Summary of promising drugs for NAFLD/NASH.

\begin{tabular}{|c|c|c|c|c|c|}
\hline Name of Drug & Mechanism of Action & Metabolic Profile & Liver Histology & $\begin{array}{l}\text { Clinical Stage } \\
\text { (Title of Trial) }\end{array}$ & Ref. \\
\hline Pioglitazone & $\operatorname{PPAR} \gamma$ agonist & $\begin{array}{r}\text { Insulin sensitivity }(\uparrow) \\
\text { Hepatic TG }(\downarrow) \\
\operatorname{ALT}(\downarrow) \\
\operatorname{AST}(\downarrow) \\
\operatorname{BW}(\uparrow)\end{array}$ & $\begin{array}{r}\text { Steatosis }(\downarrow) \\
\text { Ballooning }(\downarrow) \\
\text { Inflammation }(\downarrow) \\
\text { Fibrosis }(\downarrow) \\
\text { NAS }(\downarrow)\end{array}$ & Phase 4 trial, 2008-2014 & {$[104,105,125,212,213]$} \\
\hline Obeticholic acid (OCA) & FXR agonist & $\begin{array}{r}\text { Insulin sensitivity }(\uparrow) \\
\operatorname{ALT}(\downarrow) \\
\operatorname{AST}(\downarrow) \\
\operatorname{ALP}(\uparrow) \\
\operatorname{HDL}-\mathrm{C}(\downarrow) \\
\operatorname{LDL}-\mathrm{C}(\uparrow) \\
\mathrm{BW}(\downarrow)\end{array}$ & $\begin{array}{r} \\
\text { Steatosis }(\downarrow) \\
\text { Ballooning }(\downarrow) \\
\text { Inflammation }(\downarrow) \\
\text { Fibrosis }(\downarrow) \\
\text { NAS }(\downarrow)\end{array}$ & $\begin{array}{c}\text { Phase } 3 \text { trial, ongoing } \\
\text { since } 2017 \\
\text { (REGENERATE, } \\
\text { REVERSE) }\end{array}$ & {$[214,215]$} \\
\hline
\end{tabular}


Table 1. Cont

\begin{tabular}{|c|c|c|c|c|c|}
\hline Name of Drug & Mechanism of Action & Metabolic Profile & Liver Histology & $\begin{array}{l}\text { Clinical Stage } \\
\text { (Title of Trial) }\end{array}$ & Ref. \\
\hline Elafibranor & Dual PPAR $\alpha / \delta$ agonist & $\begin{array}{r}\text { Insulin sensitivity }(\uparrow) \\
\text { Plasma TG }(\downarrow) \\
\operatorname{ALT}(\downarrow) \\
\operatorname{AST}(-) \\
\operatorname{ALP}(\downarrow) \\
\text { BW(-) }\end{array}$ & $\begin{array}{r}\text { Steatosis }(\downarrow) \\
\operatorname{Inflammation}(\downarrow) \\
\text { Fibrosis }(\downarrow)\end{array}$ & $\begin{array}{c}\text { Phase } 3 \text { trial, ongoing } \\
\text { since } 2016 \\
\text { (RESOLVE-IT) }\end{array}$ & {$[144,150,151]$} \\
\hline Aramchol & SCD1 inhibitor & $\begin{array}{r}\text { Insulin sensitivity }(\uparrow) \\
\text { Hepatic TG( }(\downarrow) \\
\text { ALT(-) } \\
\text { AST(-) } \\
\text { BW(-) }\end{array}$ & $\begin{array}{c}\text { Steatosis }(\downarrow) \\
\text { Fibrosis }(\downarrow)\end{array}$ & $\begin{array}{l}\text { Phase } 3 \text { trial, ongoing } \\
\text { since } 2019 \text { (ARMOR) }\end{array}$ & [157] \\
\hline Liraglutide & GLP-1R agonist & $\begin{array}{r}\text { Insulin sensitivity }(\uparrow) \\
\text { Hepatic TG }(\downarrow) \\
\operatorname{ALT}(\downarrow) \\
\operatorname{AST}(-) \\
\operatorname{BW}(\downarrow)\end{array}$ & $\begin{array}{r}\text { Steatosis }(\downarrow) \\
\text { Ballooning }(\downarrow)\end{array}$ & $\begin{array}{c}\text { Phase } 3 \text { trial, ongoing } \\
\text { since } 2014 \\
\text { (CGH-LiNASH) }\end{array}$ & {$[164,216,217]$} \\
\hline Selonsertib & ASK1 inhibitor & $\begin{array}{c}\operatorname{ALT}(\downarrow) \\
\operatorname{AST}(\downarrow) \\
\operatorname{BW}(-)\end{array}$ & $\begin{array}{r}\text { Steatosis }(\downarrow) \\
\text { Ballooning }(\downarrow) \\
\text { Inflammation }(\downarrow) \\
\text { Fibrosis }(\downarrow) \\
\text { NAS }(\downarrow)\end{array}$ & $\begin{array}{l}\text { Phase } 3 \text { trial, ongoing } \\
\text { since } 2019 \text { (STELLAR3, } \\
\text { STELLAR4) }\end{array}$ & [93] \\
\hline Simtuzumab (SIM) & $\begin{array}{l}\text { LOXL2 monoclonal } \\
\text { antibody }\end{array}$ & $\begin{array}{l}\text { ALT(-) } \\
\text { AST(-) } \\
\text { BW(-) }\end{array}$ & Fibrosis(-) & Phase 2 trial, 2012-2017 & {$[218,219]$} \\
\hline Cenicriviroc (CVC) & $\begin{array}{l}\text { Dual CCR2/CCR5 } \\
\text { antagonist }\end{array}$ & $\begin{array}{l}\text { ALT(-) } \\
\text { AST(-) } \\
\text { BW(-) }\end{array}$ & $\begin{array}{r}\operatorname{Inflammation}(\downarrow) \\
\operatorname{Fibrosis}(\downarrow)\end{array}$ & $\begin{array}{l}\text { Phase } 3 \text { trial, ongoing } \\
\text { since } 2017 \text { (AURORA) }\end{array}$ & [196] \\
\hline
\end{tabular}

$((\uparrow)$ : increase, $(\downarrow)$ : decrease, $(-)$ : no significant).

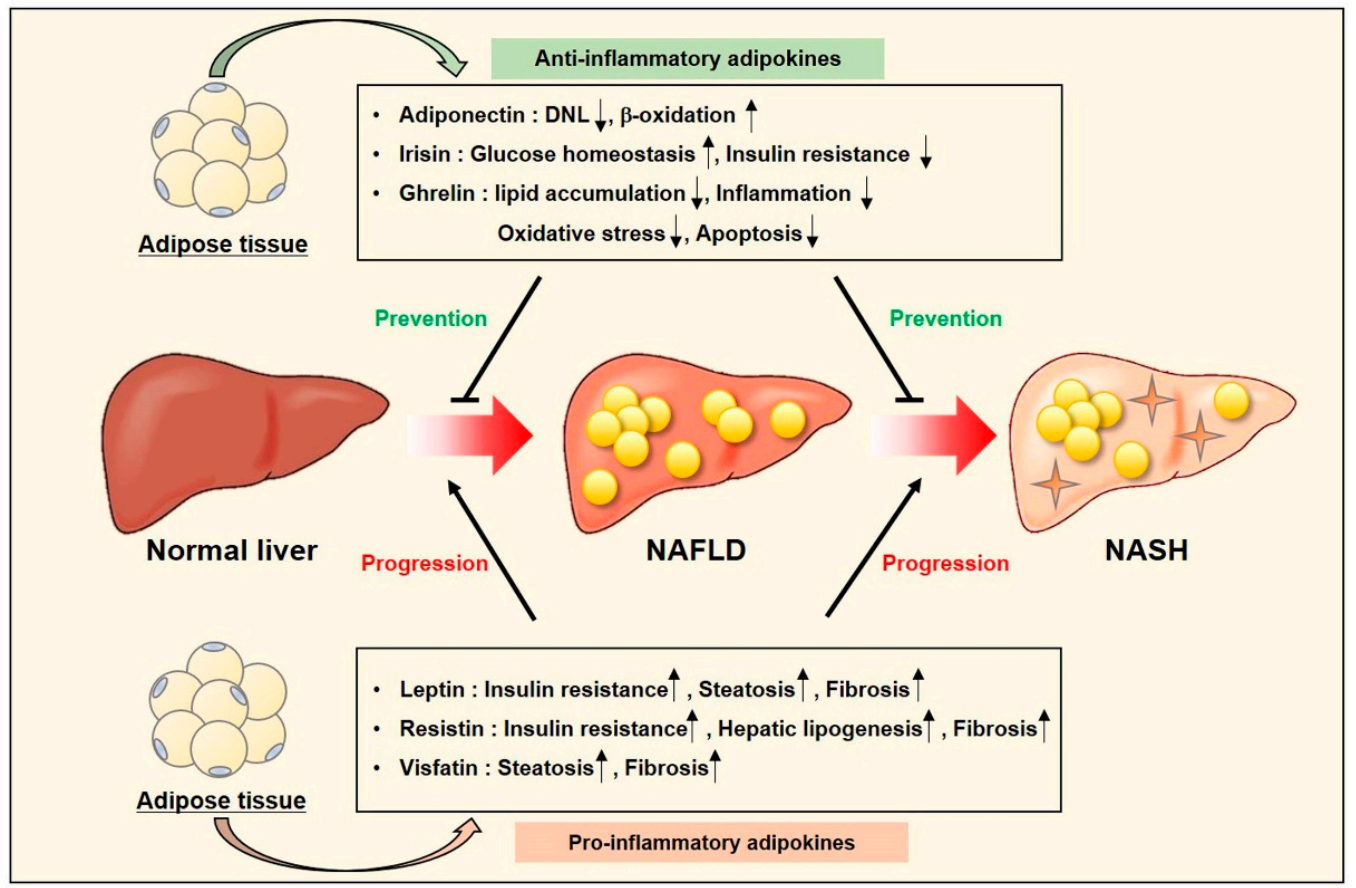

Figure 5. Adipokines as diagnostic markers and therapeutic targets in NAFLD and NASH. Adipokines that are secreted from adipose tissues are classified into anti-inflammatory adipokines and pro-inflammatory adipokines. Anti-inflammatory adipokines including adiponectin, irisin, and ghrelin inhibit the development and progression of NAFLD and NASH, whereas pro-inflammatory adipokines including leptin, resistin, and visfatin promote the development and progression of NAFLD and NASH.

\subsubsection{Adiponectin}

Adiponectin is an important adipokine that can inhibit NAFLD development. Circulating adiponectin levels were decreased in patients with NAFLD and NASH [220-222]. 
These are inversely correlated with the severity of hepatic steatosis and inflammation. Pioglitazone, an anti-diabetic drug of thiazolidinedione-type, improves liver histology and increases adiponectin levels in patients with NASH [104,125]. However, metformin, the most commonly used anti-diabetic medication, has no significant effects on the liver histology of patients with NAFLD and NASH, and reduces adiponectin levels $[107,108,223]$. Vitamin E is a potent antioxidant that protects our cells against oxidative stress [224]. It is an alternative medicine that is recommended in NAFLD and NASH. Vitamin E improves liver histology and shows some beneficial effects in non-diabetic patient with NASH, and also seems to increase adiponectin levels $[225,226]$. However, it has been found to be ineffective alone in NASH patients with type 2 diabetes $[226,227]$. In mouse models, adiponectin suppresses hepatic lipid accumulation by enhancing FA oxidation and reducing DNL $[206,228,229]$. It exerts anti-inflammation, anti-fibrotic, and anti-apoptotic effects [229]. Administration of adiponectin improves hepatic steatosis and inflammation $[228,229]$. Additionally, adiponectin expression is inversely correlated with tumor size and local recurrence $[230,231]$.

\subsubsection{Leptin}

Leptin is an appetite-suppressing hormone secreted by fat cells. It regulates food intake, body fat, and insulin sensitivity [232]. In animal models, it is thought that it improves lipid metabolism in non-adipose tissues [233]. In the liver, however, it exacerbates hepatic insulin resistance, which results in liver steatosis. It also enhances liver fibrosis $[199,233]$. Leptin administration can enhance pro-inflammatory and fibrogenic responses in the liver via procollagen I and TGF $\beta 1$ [234]. In humans, however, its effects are unclear. Circulating leptin levels are increased in patients with NASH $[235,236]$. Leptin levels are positively correlated with steatosis severity, whereas it is unclear between leptin levels and the progression of inflammation and fibrosis [235-238]. Leptin expression is positively correlated with cell proliferation in HCC, as confirmed by proliferation marker protein Ki67 [231].

\subsubsection{Resistin}

Resistin is a proinflammatory adipocyte-derived mediator of hepatic insulin resistance $[239,240]$. It is also expressed in liver cells. Resistin is associated with hepatic lipogenesis and liver fibrosis [241]. Circulating resistin levels are increased in patients with NAFLD and NASH, and circulating resistin levels in patients with NAFLD are related to the severity of steatosis, inflammation, and fibrosis [202,242,243]. Increased resistin levels are thought to be associated with insulin resistance. In individuals with NAFLD, pioglitazone treatment improves insulin sensitivity, and decreases plasma resistin levels [244].

\subsubsection{Ghrelin}

Ghrelin is an anti-inflammatory adipokine. It is an endogenous ligand for growth hormone secretagog receptor with a peptide structure that contains 28 amino acids [245]. In patients with NAFLD, lower ghrelin levels are associated with insulin resistance [246,247]. Plasma ghrelin levels are significantly correlated with liver function. However, ghrelin is not affected by pioglitazone as one of insulin sentizers [45]. During and after NAFLD development, ghrelin administration improves hepatic lipid metabolism, inflammation, oxidative stress, and apoptosis [210]. In mouse models, ghrelin reduces the TG content and the cytokins TNF- $\alpha$ and IL-6, and attenuates lipotoxicity through autophagy sitimulation and NF-kB inhibition [248]. Collectively, ghrelin could be a biomarker for diagnosis and a therapeutic target for treatment of NALFD.

\subsubsection{Irisin}

Irisin is a myokine secreted from skeletal muscle upon shivering and exercise stimulation [249]. Fibronectin type III domain containing 5 precursors (FNDC5) is the precursor of irisin. FNDC5/irisin promotes the thermogenic program in adipose tisseus through ERK and p38 pathways [250]. It improves glucose homeostasis and insulin resistance, and 
induces weight loss [251]. Recently, FNDC5/irisin was induced during adipocyte differentiation, and can be over-secreted from human obese visceral (VAT) and subcutaneous (SAT) adipose tissues [252]. It is thought of as a compensatory effect. In line with this, circulating irisin levels are increased in patients with NAFLD, and are positively related with portal inflammation [218]. They are also believed to act as a compensatory effect.

\subsubsection{Visfatin}

Visfatin is one of the proinflammatory adipokines. Serum visfatin levels are raised in type 2 diabetes and insulin resistant conditions $[253,254]$. Circulating visfatin levels are also increased in patients with NAFLD, and are associated with the severity of hepatic steatosis and fibrosis $[204,255]$. However, they are not affected by insulin sensitizers including pioglitazone, rosiglitazone, and metformin $[256,257]$.

\section{NAFLD/NASH-Derived HCC}

\subsection{The Pathogenesis of NAFLD/NASH-Derived HCC}

HCC is the third most common cause of cancer-related mortality [258]. NAFLD and NASH-related HCC is the fastest growing indication for liver transplantation $[259,260]$. Cirrhosis is only present in approximately $60 \%$ of patients with NAFLD and NASHassociated HCC [259]. This suggests that HCC can be induced from NAFLD/NASH without cirrhosis. Therefore, it is thought that "inflammatory factors" will also play a critical role in NAFLD/NASH-derived HCC.

\subsubsection{Gut-Derived Endotoxin}

As mentioned above, gut-derived endotoxins as alternative inflammatory factors play an important role in the development of NAFLD and NASH. The levels of LPS, known as endotoxins, are also increased in portal and peripheral veins of patients with HCC [261]. They significantly promote the invasive potential and induce the epithelial-mesenchymal transition (EMT), although they also inhibit tumor growth [262]. LPS activates JNK and MAPK via TLR4 in HCC cells, whereas inhibition of JNK/MAPK significantly reduces EMT occurrence [262]. Therefor, the LPS-TLR4 signaling could be one of the promising pathways regulating the progression from NAFLD to NASH to HCC [263].

\subsubsection{Adipokines}

Adipokines are inflammatory factors related with HCC development. Adiponectin expression in human HCC is inversely correlated with tumor size [230]. It enhances phosphorylation of c-Jun N-terminal kinase (JNK) and activates caspase-3, leading to apoptosis in HCC [230]. Inhibition of JNK phosphorylation prevents anti-apoptotic effects of adiponectin [230]. Adiponectin exerts chmoprotective and hepatoprotective effects via sulfatase2 (SULF2) in HCC [264]. Loss of adiponectin promotes fibrosis and HCC progression in a cholin-deficient NASH mouse model [265]. On the other hand, high levels of circulating adiponectin make it possible to predict the consecutive development of HCC and poor HCC survival $[266,267]$. Further, adiponectin inhibits the oncogenic effects of leptin on cell proliferation, migration, and invasion in HCC [231].

Leptin expression is increased in both hepatoma tissues and cell lines [268]. Regulatory T-cells (Tregs), effector CD4(+), and CD8(+) T-cells stimulate expression of the leptin receptor (LEPR) in the liver after HCC induction [268]. Macrophage and dendritic cells upregulate LEPR expression on the T-cell. Leptin inhibits Treg activation and function [268]. Increased leptin expression in HCC is associated with the expression of human telomerase reverse transcriptase (hTERT) [269]. Leptin might play a critical role in obesity-related tumorigenesis. Adipokines including adiponectin and leptin represent key players in obesity-related disorders and might be involved in the pathogenesis of NAFLD and HCC. 


\subsection{Diagnostic and Therapeutic Targets in NAFLD/NASH-Derived HCC: Hepatokines}

The liver is a secretory organ that releases specific cytokines, termed hepatokines [43]. Adipose tissues in NAFLD, characterized by hepatic TG accumulation, play a critical role in promoting FFA uptake into the liver through lipolysis [48]. Therefore, the role of adipokines from adipose tissues, which provide the major energy source for the development of NAFLD, will be very important in the liver. On the other hand, lipid droplet accumulation itself does not affect inflammation and is considered as simple steatosis. The progression from NAFLD to NASH to HCC needs additional factors such as oxidative stress, mitochondrial dysfunction, and ER-stress [75,270,271]. Another important factor driving NASH in simple steatosis is free non-esterified cholesterol and its oxidized derivatives [272-274]. They are cytotoxic and exert synergistic effects with TNF, which is markedly increased in patients with NASH [274]. Therefore, hepatokines secreted from the liver might exert a more potent ability in the progression of NAFLD and NASH to HCC (Figure 6).

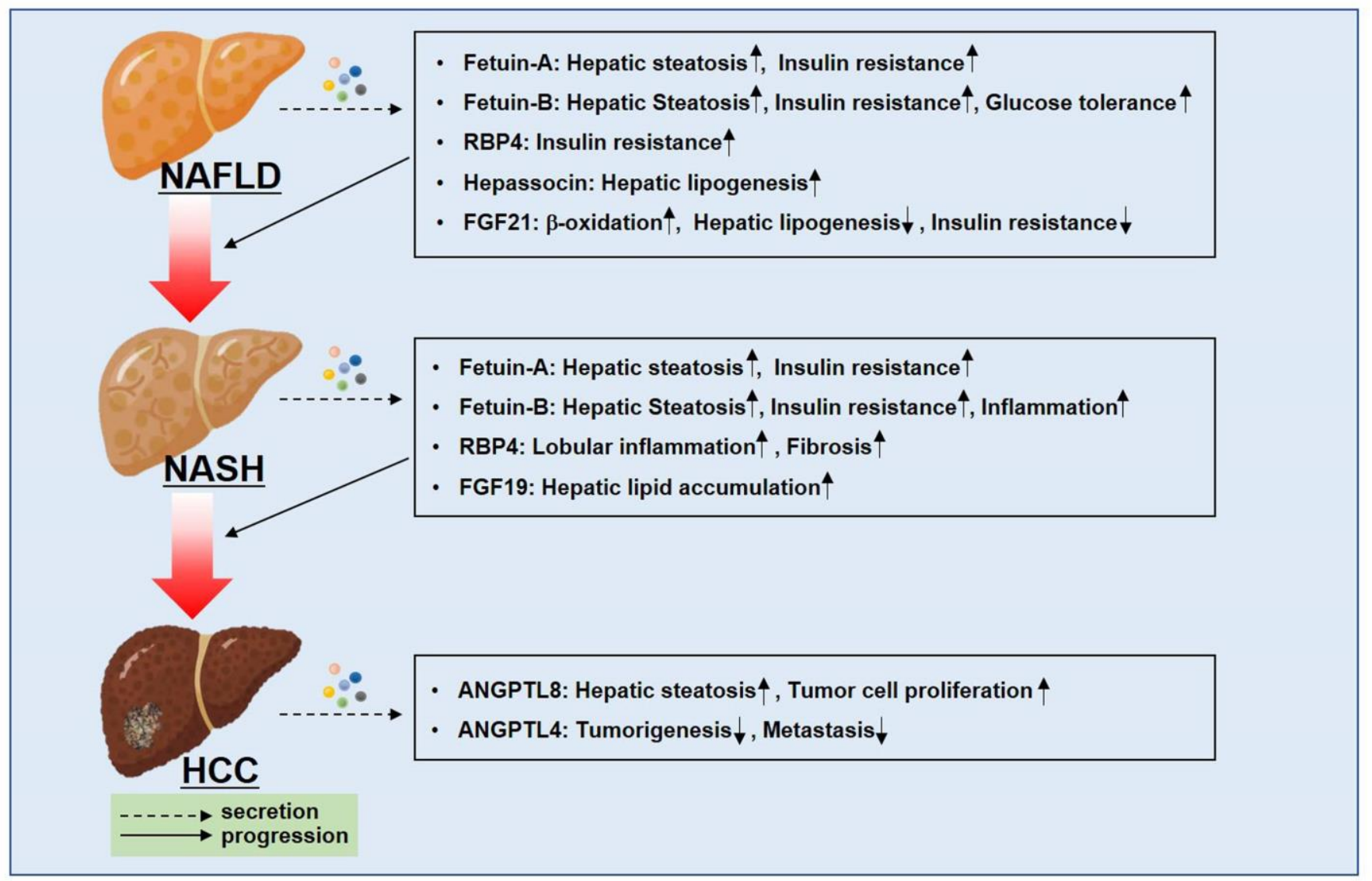

Figure 6. Hepatokines that are secreted from the liver are closely associated with the progression from NAFLD to NASH to HCC. Hepatokines including Fetuin-A, Fetuin-B, RBP4, and FGF19 play an important role in NAFLD and NASH. They are associated with hepatic lipid accumulation, insulin resistance, and inflammatory signaling pathways. Additionally, ANGPTL4 and 8 tend to function in opposite ways in HCC tumorigenesis.

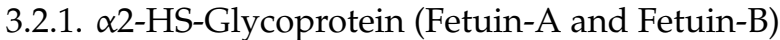

Fetuin-A, one of the liver secreted glycoproteins, is known as the first hepatokine shown to associated with metabolic diseases $[275,276]$. Fetuin-A is positively associated with hepatic steatosis and insulin resistance [277-279]. Its levels are increased in patients with NAFLD, NASH, and type 2 diabetes [280,281]. As an important source of NAFLD development, FFA enhances pro-inflammatory Fetuin-A expression [7]. FFA-induced Fetuin-A functions as an endogenous ligand of Toll-like receptor 4 (TLR4), and exacerbates lipid-mediated insulin resistance [282,283]. FFA can also enhances NF-kB recruitment to 
the Fetuin-A promoter and increases synthesis and the secretion of Fetuin-A in primary hepatocytes [284]. Pioglitazone significantlly suppresses serum Fetuin-A levels in patients with type 2 diabetes [285]. Pioglitazone inhibits mRNA and protein levels of hepatic Fetuin$\mathrm{A}$, and oral administration of pioglitazone in mice partially ameliorates insulin resistance with decreases on hepatic fetuin-A expression [286]. These data suggest that Fetuin-A might be a therapeutic target for treatment of NAFLD/NASH and insulin resistance. Additionally, circulating Fetuin-A levels are increased in patients with HCC $[287,288]$. Fetuin-B might also be an independent indicator of NAFLD development [289]. It induces hepatic steatosis, insulin resistance, and glucose intolerance $[277,290]$. It decreases AMPK phosphorylation levels and aggravates LXR/SREBP1c-mediate hepatic lipogenesis [291]. On the other hand, circulating Fetuin-A and Fetuin-B levels in patients with NAFLD are negatively associated with liver fibrosis [292,293].

\subsubsection{Retinol Binding Protein 4 (RBP4)}

The liver plays a central role in vitamin A metabolism. In NAFLD, hepatic vitamin A homeostasis is disrupted [294,295]. RBP4 is a specific retinol/vitamin A carrier protein secreted from the liver. It is also secreted from adipocytes and macrophages [296]. Serum RBP4 levels are associated with NAFLD development [297-299]. Circulating RBP4 levels are positively correlated with the body mass index (BMI) and insulin resistance [300,301]. In moderate/severe NASH, high levels of hepatic RBP4 corelated with lobular inflammation and fibrosis scores [302], whereas other studies indicate that both serum and hepatic RBP4 levels negatively correlate with the liver fibrosis stage [299]. In cirrhosis, RBP4 expression improves hepatic glucose production, but not insulin sensitivity [303]. It is true that vitamin A homeostasis is broken and deficient as a result of liver fibrosis and cirrhosis [294]. Importantly, high RBP4 levels could be a marker of NAFLD development, and the lower levels of RBP4 may also be an indicator of the progression ot NASH with fibrosis among NAFLD disease stages [297,298].

\subsubsection{Hepassocin (HPS)}

HPS, which is known as hepatocyte-derived fibrinogen-related protein 1 (HFREP-1), is a hepatokine that is involved in liver regeneration [304]. In mice and patients with NAFLD, plasma HPS levels are increased [305]. HPS overexpression increased hepatic lipid accumulation, and NAFLD activity scores (NAS), whereas its deletion improves them $[305,306]$. Serum HPS levels are correlated with the levels of inflammatory cytokines and lipogenic gene expression [306]. HPS-induced hepatic steatosis is triggered through an extracellular signal-regulated kinase 1/2 (ERK1/2)-dependent pathway [306-308]. FFA induces HPS expression [309,310]. Oleic acid, the most wildely destributed unsaturated FA, induces HPS expression through signal transducer and activator of transcription 3 (STAT3) signaling [309]. Palmitate, the most abundant saturated FA, induces HPS expression through ER stress-mediated p38 activation by C/EBP $\beta$ in primary hepatocytes [310]. Additionally, hepatic HPS expression is increased by partial hepatectomy in mice, and is induced by the hepatocyte nuclear factor 1alpha (HNF1 $\alpha$ ) through the IL-6/STAT3 pathway [311]. HPS administration protect against liver injury and improves survival in rats with hepatitis [312]. Liver-specific HPS expression is repressed with the downregulation of HNF1 $\alpha$ in HCC [311,313].

\subsubsection{Fibroblast Growth Factors 19 and 21 (FGF19 and FGF21)}

FGF19 and FGF21 are the FGF19 subfamily that requires the Klotho proteins as cofactors. They activate FGFR4 together with Klotho, which is abundantly expressed in hepatocytes [314,315]. FGF19 and FGF21 regulate bile acid, lipid, and the glucose metabolism [314,316]. 
Fibroblast Growth Factors 19 (FGF19)

In NASH, the levels of serum FGF19, fibroblast growth factor receptor 4 (FGFR4), and bile acids are significantly increased, and results in impaired FXR and FGFR4-mediated signaling [317,318]. In patients with NASH, FAF analogue significantly reduces hepatic lipid accumulation. On the other hand, upregulation of FGF19 is associated with the progression, recurrence, and poorer prognosis of HCC [319-321]. The $\beta$-Klotho proteins are also increased in liver and serum of patients with HCC [321,322].

\section{Fibroblast Growth Factors 21 (FGF21)}

The hepatokine FGF21 has the beneficial effects on hepatic lipid metabolism. It enhances lipid oxidation, suppresses de novo lipogenesis, and improves insulin resistance by inhibiting mammalian target of rapamycin (mTOR) [323-325]. Hepatic FGF21 expression is positively related with adipocity and intrahepatic triglycerids, and its serum levels are significantly increased in patiens with obesity, NAFLD, and type 2 diabetes [326-328]. Serum FGF21 levels are increased in obese children with or without NAFLD [329,330]. Elevated serum FGF21 is thought to be able to an independent marker associated with the development of metabolic syndrome [326]. Serum FGF21 levels are increased according to steatosis severity, and are positively correlated with NAFLD activity scores (NASs) [331,332]. Patients with an advanced NASH can be characterized by circulating FGF21 levels combined with inflammatory factors (cytokeratin-18-M30 antigen, IL-1Ra, pigment epithelium-drived factor, and osteoprotegrin) [333]. Increases in serum and hepatic FGF21 levels are observed in cirrhosis and HCC [334].

\subsubsection{Angiopoietin-Like Protein 8 (ANGPTL8)}

ANGPTL8/betatrophin is circulating a hepatokine that is known as TD26 and lipasin [335]. It is highly expressed in liver and visceral adipose tissue [335,336]. It is associated with hepatic steatosis and increased plasma triacylglycerol levels [336-338]. ANGPTL8 overexpression in brown adipose tissue (BAT) enhances lipoprotein lipase activity (LPL) activity and TG uptake $[339,340]$. Serum ANGPTL8 levels are significantly increased in patients with prediabetes and type 2 diabetes [341]. It has reported that ANGPTL8 is involved in proliferation of pancreatic beta-cells and regulation of glucose and lipid metabolism in mice [342-344]. Additionally, ANGPTL8 expression is markedly increased in HCC [337]. It interacts with SREBP-1, and resultingly promotes lipogenesis and tumor cell proliferation in HCC $[337,338]$. Therefore, it is thought that it is positively correlated with the tumor size. ANGPTL8 requires ANGPTL3 rather than regulating LPL alone $[339,345,346]$. ANGPTL3 regulates TG metabolism by directly inhibiting LPL [339,347,348]. ANGPTL4, which is abundantly expressed in the liver and adipose tissues, can also regulate TG metabolism by suppressing LPL activity [339,349]. However, ANGPTL4 expression is decreased in HCC, and overexpression of ANGPTL4 suppresses HCC tumorigenesis and metastasis [350].

\section{Conclusions}

In the last 20 years, the proportion of HCC patients with non-viral etiology has been rapidly increasing. For that reason, the importance of NAFLD/NASH-derived HCC has been emerging. Currently, it is true that the treatment of patients with NAFLD/NASH is generally performed using medication for patients with type 2 diabetes and hyperlipidemia. The side effects that appear with long-term use cannot be ignored. Therefore, appropriate therapeutic targets and FDA-approved therapies are urgent. It is thought that the reasons for failing to develop a treatment for patients with NAFLD/NASH despite ongoing attempts are as follows: $1>$ unclear pathogenesis, $2>$ lack of effects, and $3>$ safety problems. Adipose tissue and the liver are the major organs associated with the lipid metabolism. Therefore, it is necessary to observe adipokines and hepatokines, which can be diagnostic and therapeutic targets, along with the signaling pathway targeted by the current treatments. Additionally, it would be good to make an in-depth observation through the classification according to the cause of NAFLD. It will provide an important 
point of view for controlling the metabolic phenotype from NAFLD to NASH to HCC. Currently, it is acceptable to consider that NAFLD is caused by a concert of various factors including nutritional factors, gut microbiota, and genetic and epigenetic factors, as well as adipokines and hepatokines. In order to find an appropriate treatment, it is necessary to observe various factors in a broader perspective.

Author Contributions: Conceptualization, K.-J.O. and H.K.; writing-original draft preparation, K.-J.O., K.-H.B., and H.K.; Figure elaboration, D.S.L., T.H.A., and H.-J.P.; writing-review and editing, K.-J.O. and H.K.; funding acquisition, K.-J.O., K.-H.B., and W.K.K.; supervision, K.-J.O. All authors have read and agreed to the published version of the manuscript.

Funding: This work was supported by grants from the KRIBB (KGM1052112 and KGM5392111) and the National Research Foundation of Korea (2020R1A2C2102308 and 2020R1A2C2007111).

Conflicts of Interest: The authors declare no conflict of interest.

\section{References}

1. Unnikrishnan, R.; Pradeepa, R.; Joshi, S.R.; Mohan, V. Type 2 Diabetes: Demystifying the Global Epidemic. Diabetes 2017, 66, 1432-1442. [CrossRef]

2. Khan, M.A.B.; Hashim, M.J.; King, J.K.; Govender, R.D.; Mustafa, H.; Al Kaabi, J. Epidemiology of Type 2 Diabetes-Global Burden of Disease and Forecasted Trends. J. Epidemiol. Glob. Health 2020, 10, 107-111. [CrossRef]

3. Satman, I.; Omer, B.; Tutuncu, Y.; Kalaca, S.; Gedik, S.; Dinccag, N.; Karsidag, K.; Genc, S.; Telci, A.; Canbaz, B.; et al. Twelve-year trends in the prevalence and risk factors of diabetes and prediabetes in Turkish adults. Eur. J. Epidemiol. 2013, 28, 169-180. [CrossRef] [PubMed]

4. Masmiquel, L.; Leiter, L.A.; Vidal, J.; Bain, S.; Petrie, J.; Franek, E.; Raz, I.; Comlekci, A.; Jacob, S.; van Gaal, L.; et al. LEADER 5: Prevalence and cardiometabolic impact of obesity in cardiovascular high-risk patients with type 2 diabetes mellitus: Baseline global data from the LEADER trial. Cardiovasc. Diabetol. 2016, 10, 29. [CrossRef] [PubMed]

5. Ng, A.C.T.; Delgado, V.; Borlaug, B.A.; Bax, J.J. Diabesity: The combined burden of obesity and diabetes on heart disease and the role of imaging. Nat. Rev. Cardiol. 2021, 18, 291-304. [CrossRef] [PubMed]

6. Chaput, J.P.; Klingenberg, L.; Astrup, A.; Sjödin, A.M. Modern sedentary activities promote overconsumption of food in our current obesogenic environment. Obes. Rev. 2011, 12, e12-e20. [CrossRef] [PubMed]

7. González-Gross, M.; Meléndez, A. Sedentarism, active lifestyle and sport: Impact on health and obesity prevention. Nutr. Hosp. 2013, 5, 89-98.

8. Younossi, Z.M. Non-alcoholic fatty liver disease-A global public health perspective. J. Hepatol. 2019, 70, 531-544. [CrossRef] [PubMed]

9. Younossi, Z.; Tacke, F.; Arrese, M.; Chander Sharma, B.; Mostafa, I.; Bugianesi, E.; Wai-Sun Wong, V.; Yilmaz, Y.; George, J.; Fan, J.; et al. Global Perspectives on Nonalcoholic Fatty Liver Disease and Nonalcoholic Steatohepatitis. Hepatology 2019, 69, $2672-2682$. [CrossRef] [PubMed]

10. Bellentani, S. The epidemiology of non-alcoholic fatty liver disease. Liver Int. 2017, 1, 81-84. [CrossRef] [PubMed]

11. Kawano, Y.; Cohen, D.E. Mechanisms of hepatic triglyceride accumulation in non-alcoholic fatty liver disease. J. Gastroenterol. 2013, 48, 434-441. [CrossRef]

12. Sunny, N.E.; Bril, F.; Cusi, K. Mitochondrial adaptation in nonalcoholic fatty liver disease: Novel mechanisms and treatment strategies. Trends Endocrinol. Metab. 2017, 28, 250-260. [CrossRef] [PubMed]

13. Abd El-Kader, S.M.; El-Den Ashmawy, E.M. Non-alcoholic fatty liver disease: The diagnosis and management. World J. Hepatol. 2015, 7, 846-858. [CrossRef]

14. Arulanandan, A.; Loomba, R. Non-invasive Testing for NASH and NASH with Advanced Fibrosis: Are We There Yet? Curr. Hepatol. Rep. 2015, 14, 109-118. [CrossRef]

15. Chalasani, N.; Younossi, Z.; Lavine, J.E.; Charlton, M.; Cusi, K.; Rinella, M.; Harrison, S.A.; Brunt, E.M.; Sanyal, A.J. The diagnosis and management of nonalcoholic fatty liver disease: Practice guidance from the American Association for the Study of Liver Diseases. Hepatology 2018, 67, 328-357. [CrossRef] [PubMed]

16. Clark, J.M. The epidemiology of nonalcoholic fatty liver disease in adults. J. Clin. Gastroenterol. 2006, 1, S5-S10.

17. Wong, V.W.; Chan, W.K.; Chitturi, S.; Chawla, Y.; Dan, Y.Y.; Duseja, A.; Fan, J.; Goh, K.L.; Hamaguchi, M.; Hashimoto, E.; et al. Asia-Pacific Working Party on Non-alcoholic Fatty Liver Disease guidelines 2017-Part 1: Definition, risk factors and assessment. J. Gastroenterol. Hepatol. 2018, 33, 70-85. [CrossRef]

18. Mahjoubin-Tehran, M.; De Vincentis, A.; Mikhailidis, D.P.; Atkin, S.L.; Mantzoros, C.S.; Jamialahmadi, T.; Sahebkar, A. Nonalcoholic fatty liver disease and steatohepatitis: State of the art on effective therapeutics based on the gold standard method for diagnosis. Mol. Metab. 2020, 13, 101049. [CrossRef] [PubMed]

19. Calzadilla Bertot, L.; Adams, L.A. The natural course of non-alcoholic fatty liver disease. Int. J. Mol. Sci. 2016, 17, 774. [CrossRef] [PubMed] 
20. Loomba, R.; Adams, L.A. The 20\% Rule of NASH Progression: The Natural History of Advanced Fibrosis and Cirrhosis Caused by NASH. Hepatology 2019, 70, 1885-1888. [CrossRef] [PubMed]

21. Wong, S.W.; Ting, Y.W.; Chan, W.K. Epidemiology of non-alcoholic fatty liver disease-related hepatocellular carcinoma and its implications. JGH Open 2018, 2, 235-241. [CrossRef]

22. Piscaglia, F.; Svegliati-Baroni, G.; Barchetti, A.; Pecorelli, A.; Marinelli, S.; Tiribelli, C.; Bellentani, S. Clinical patterns of hepatocellular carcinoma in nonalcoholic fatty liver disease: A multicenter prospective study. Hepatology 2016, 63, 827-838. [CrossRef]

23. Mittal, S.; Sada, Y.H.; El-Serag, H.B.; Kanwal, F.; Duan, Z.; Temple, S.; May, S.B.; Kramer, J.R.; Richardson, P.A.; Davila, J.A. Temporal trends of nonalcoholic fatty liver disease-related hepatocellular carcinoma in the veteran affairs population. Clin. Gastroenterol. Hepatol. 2015, 13, 594-601. [CrossRef] [PubMed]

24. Benhammou, J.N.; Lin, J.; Hussain, S.K.; El-Kabany, M. Emerging risk factors for nonalcoholic fatty liver disease associated hepatocellular carcinoma. Hepatoma Res. 2020, 6, 35. [CrossRef]

25. Huang, D.Q.; El-Serag, H.B.; Loomba, R. Global epidemiology of NAFLD-related HCC: Trends, predictions, risk factors and prevention. Nat. Rev. Gastroenterol. Hepatol. 2021, 18, 223-238. [CrossRef]

26. Said, A.; Ghufran, A. Epidemic of non-alcoholic fatty liver disease and hepatocellular carcinoma. World J. Clin. Oncol. 2017, 8, 429-436. [CrossRef] [PubMed]

27. Anstee, Q.M.; McPherson, S.; Day, C.P. How big a problem is non-alcoholic fatty liver disease? BMJ 2011, 343, d3897. [CrossRef] [PubMed]

28. Xia, M.F.; Bian, H.; Gao, X. NAFLD and Diabetes: Two Sides of the Same Coin? Rationale for Gene-Based Personalized NAFLD Treatment. Front. Pharmacol. 2019, 10, 877. [CrossRef] [PubMed]

29. Tanase, D.M.; Gosav, E.M.; Costea, C.F.; Ciocoiu, M.; Lacatusu, C.M.; Maranduca, M.A.; Ouatu, A.; Floria, M. The Intricate Relationship between Type 2 Diabetes Mellitus (T2DM), Insulin Resistance (IR), and Nonalcoholic Fatty Liver Disease (NAFLD). J. Diabetes Res. 2020, 2020, 3920196. [CrossRef] [PubMed]

30. Tomah, S.; Alkhouri, N.; Hamdy, O. Nonalcoholic fatty liver disease and type 2 diabetes: Where do Diabetologists stand? Clin. Diabetes Endocrinol. 2020, 6, 9. [CrossRef] [PubMed]

31. Polyzos, S.A.; Kountouras, J.; Mantzoros, C.S. Obesity and nonalcoholic fatty liver disease: From pathophysiology to therapeutics. Metabolism 2019, 92, 82-97. [CrossRef] [PubMed]

32. Hazlehurst, J.M.; Woods, C.; Marjot, T.; Cobbold, J.F.; Tomlinson, J.W. Non-alcoholic fatty liver disease and diabetes. Metabolism 2016, 65, 1096-1108. [CrossRef] [PubMed]

33. Jarvis, H.; Craig, D.; Barker, R.; Spiers, G.; Stow, D.; Anstee, Q.M.; Hanratty, B. Metabolic risk factors and incident advanced liver disease in non-alcoholic fatty liver disease (NAFLD): A systematic review and meta-analysis of population-based observational studies. PLoS Med. 2020, 17, e1003100. [CrossRef] [PubMed]

34. Fitzmorris, P.; Shoreibah, M.; Anand, B.S.; Singal, A.K. Management of hepatocellular carcinoma. J. Cancer Res. Clin. Oncol. 2015, 141, 861-876. [CrossRef]

35. Mlynarsky, L.; Menachem, Y.; Shibolet, O. Treatment of hepatocellular carcinoma: Steps forward but still a long way to go. World J. Hepatol. 2015, 7, 566-574. [CrossRef]

36. Goto, K.; Roca Suarez, A.A.; Wrensch, F.; Baumert, T.F.; Lupberger, J. Hepatitis C Virus and Hepatocellular Carcinoma: When the Host Loses Its Grip. Int. J. Mol. Sci. 2020, 21, 3057. [CrossRef] [PubMed]

37. Baumert, T.F.; Jühling, F.; Ono, A.; Hoshida, Y. Hepatitis C-related hepatocellular carcinoma in the era of new generation antivirals BMC Med. 2017, 15, 52. [CrossRef] [PubMed]

38. Jemal, A.; Bray, F.; Center, M.M.; Ferlay, J.; Ward, E.; Forman, D. Global cancer statistics. CA Cancer J. Clin. 2011, 61, 69-90. [CrossRef] [PubMed]

39. Enomoto, H.; Ueno, Y.; Hiasa, Y.; Nishikawa, H.; Hige, S.; Takikawa, Y.; Taniai, M.; Ishikawa, T.; Yasui, K.; Takaki, A.; et al. Japan Etiology of Liver Cirrhosis Study Group in the 54th Annual Meeting of JSH. The transition in the etiologies of hepatocellular carcinoma-complicated liver cirrhosis in a nationwide survey of Japan. J. Gastroenterol. 2021, 56, 158-167. [CrossRef] [PubMed]

40. Noda, Y.; Kawaguchi, T.; Kuromatsu, R.; Komukai, S.; Nakano, M.; Niizeki, T.; Koga, H.; Kawaguchi, A.; Torimura, T. Prognostic profile of patients with non-viral hepatocellular carcinoma: A comparative study with hepatitis $C$ virus-related hepatocellular carcinoma using data mining analysis. Oncol. Lett. 2019, 18, 227-236. [CrossRef] [PubMed]

41. Akkız, H. Hepatocellular Carcinoma: From Molecular Basis to Novel Treatment Approaches. Can. J. Gastroenterol. Hepatol. 2019, 2019, 4970731. [CrossRef] [PubMed]

42. Kanda, T.; Goto, T.; Hirotsu, Y.; Masuzaki, R.; Moriyama, M.; Omata, M. Molecular Mechanisms: Connections between Nonalcoholic Fatty Liver Disease, Steatohepatitis and Hepatocellular Carcinoma. Int. J. Mol. Sci. 2020, 21, 1525. [CrossRef] [PubMed]

43. Oh, K.J.; Lee, D.S.; Kim, W.K.; Han, B.S.; Lee, S.C.; Bae, K.H. Metabolic Adaptation in Obesity and Type II Diabetes: Myokines, Adipokines and Hepatokines. Int. J. Mol. Sci. 2016, 18, 8. [CrossRef] [PubMed]

44. Lee, M.W.; Lee, M.; Oh, K.J. Adipose Tissue-Derived Signatures for Obesity and Type 2 Diabetes: Adipokines, Batokines and MicroRNAs. J. Clin. Med. 2019, 8, 854. [CrossRef]

45. Kim, W.K.; Bae, K.H.; Lee, S.C.; Oh, K.J. The Latest Insights into Adipokines in Diabetes. J. Clin. Med. 2019, 8, 1874. [CrossRef] [PubMed] 
46. David Højland, I.; Lykkesfeldt, J.; Tveden-Nyborg, P. Molecular mechanisms of hepatic lipid accumulation in non-alcoholic fatty liver disease. Cell Mol. Life Sci. 2018, 75, 3313-3327. [CrossRef]

47. Fabbrini, E.; Magkos, F. Hepatic Steatosis as a Marker of Metabolic Dysfunction. Nutrients 2015, 7, 4995-5019. [CrossRef] [PubMed]

48. Donnelly, K.L.; Smith, C.I.; Schwarzenberg, S.J.; Jessurun, J.; Boldt, M.D.; Parks, E.J. Sources of fatty acids stored in liver and secreted via lipoproteins in patients with nonalcoholic fatty liver disease. J. Clin. Investig. 2005, 115, 1343-1351. [CrossRef] [PubMed]

49. Michele, A.-B.; David, E.C. Triglyceride metabolism in the liver. Compr. Physiol. 2017, 8, 1-8.

50. Bechmann, L.P.; Hannivoort, R.A.; Gerken, G.; Hotamisligil, G.S.; Trauner, M.; Canbay, A. The interaction of hepatic lipid and glucose metabolism in liver diseases. J. Hepatol. 2012, 56, 952-964. [CrossRef]

51. Diraison, F.; Moulin, P.; Beylot, M. Contribution of hepatic de novo lipogenesis and reesterification of plasma non esterified fatty acids to plasma triglyceride synthesis during non-alcoholic fatty liver disease. Diabetes Metab. 2003, 29, 478-485. [CrossRef]

52. Chiu, S.; Mulligan, K.; Schwarz, J.M. Dietary carbohydrates and fatty liver disease: De novo lipogenesis. Curr. Opin. Clin. Nutr. Metab. Care 2018, 21, 277-282. [CrossRef] [PubMed]

53. Lambert, J.E.; Ramos-Roman, M.A.; Browning, J.D.; Parks, E.J. Increased de novo lipogenesis is a distinct characteristic of individuals with nonalcoholic fatty liver disease. Gastroenterology 2014, 146, 726-735. [CrossRef] [PubMed]

54. Linden, A.G.; Li, S.; Choi, H.Y.; Fang, F.; Fukasawa, M.; Uyeda, K.; Hammer, R.E.; Horton, J.D.; Engelking, L.J.; Liang, G. Interplay between ChREBP and SREBP-1c coordinates postprandial glycolysis and lipogenesis in livers of mice. J. Lipid Res. 2018, 59, 475-487. [CrossRef] [PubMed]

55. Dentin, R.; Girard, J.; Postic, C. Carbohydrate responsive element binding protein (ChREBP) and sterol regulatory element binding protein-1c (SREBP-1c): Two key regulators of glucose metabolism and lipid synthesis in liver. Biochimie 2005, 87, 81-86. [CrossRef] [PubMed]

56. Day, C.P.; James, O.F. Steatohepatitis: A tale of two “hits”? Gastroenterology 1998, 114, 842-845. [CrossRef]

57. Arrese, M.; Cabrera, D.; Kalergis, A.M.; Feldstein, A.E. Innate immunity and inflammation in NAFLD/NASH. Dig. Dis. Sci. 2016, 61, 1294-1303. [CrossRef] [PubMed]

58. Fukui, H. Gut-liver axis in liver cirrhosis: How to manage leaky gut and endotoxemia. World J. Hepatol. 2015, 7, 425-442. [CrossRef] [PubMed]

59. Sun, P.P.; Perianayagam, M.C.; Jaber, B.L. Endotoxin-binding affinity of sevelamer: A potential novel anti-inflammatory mechanism. Kidney Int. Suppl. 2009, 114, S20-S25. [CrossRef] [PubMed]

60. Ju, C.; Tacke, F. Hepatic macrophages in homeostasis and liver diseases: From pathogenesis to novel therapeutic strategies. Cell Mol. Immunol. 2016, 13, 316-327. [CrossRef]

61. Chakaroun, R.M.; Massier, L.; Kovacs, P. Gut Microbiome, Intestinal Permeability, and Tissue Bacteria in Metabolic Disease: Perpetrators or Bystanders? Nutrients 2020, 12, 1082. [CrossRef] [PubMed]

62. Ghoshal, S.; Witta, J.; de Zhong, J.; Villiers, W.; Eckhardt, E. Chylomicrons promote intestinal absorption of lipopolysaccharides. J. Lipid Res. 2009, 50, 90-97. [CrossRef] [PubMed]

63. Carpino, G.; Del Ben, M.; Pastori, D.; Carnevale, R.; Baratta, F.; Overi, D.; Francis, H.; Cardinale, V.; Onori, P.; Safarikia, S.; et al. Increased Liver Localization of Lipopolysaccharides in Human and Experimental NAFLD. Hepatology 2020, 72, 470-485. [CrossRef] [PubMed]

64. Gäbele, E.; Dostert, K.; Hofmann, C.; Wiest, R.; Schölmerich, J.; Hellerbrand, C.; Obermeier, F. DSS induced colitis increases portal LPS levels and enhances hepatic inflammation and fibrogenesis in experimental NASH. J. Hepatol. 2011, 55, 1391-1399. [CrossRef] [PubMed]

65. Harte, A.L.; da Silva, N.F.; Creely, S.J.; McGee, K.C.; Billyard, T.; Youssef-Elabd, E.M.; Tripathi, G.; Ashour, E.; Abdalla, M.S.; Sharada, H.M.; et al. Elevated endotoxin levels in non-alcoholic fatty liver disease. J. Inflamm. 2010, 7, 15. [CrossRef] [PubMed]

66. Miele, L.; Valenza, V.; La Torre, G.; Montalto, M.; Cammarota, G.; Ricci, R.; Mascianà, R.; Forgione, A.; Gabrieli, M.L.; Perotti, G.; et al. Increased intestinal permeability and tight junction alterations in nonalcoholic fatty liver disease. Hepatology 2009, 49, 1877-1887. [CrossRef]

67. Cani, P.D.; Amar, J.; Iglesias, M.A.; Poggi, M.; Knauf, C.; Bastelica, D.; Neyrinck, A.M.; Fava, F.; Tuohy, K.M.; Chabo, C.; et al. Metabolic endotoxemia initiates obesity and insulin resistance. Diabetes 2007, 56, 1761-1772. [CrossRef] [PubMed]

68. Kudo, H.; Takahara, T.; Yata, Y.; Kawai, K.; Zhang, W.; Sugiyama, T. Lipopolysaccharide triggered TNF- $\alpha$-induced hepatocyte apoptosis in a murine non-alcoholic steatohepatitis model. J. Hepatol. 2009, 51, 168-175. [CrossRef] [PubMed]

69. Leung, C.; Rivera, L.; Furness, J.B.; Angus, P.W. The role of the gut microbiota in nonalcoholic fatty liver disease. Nat. Rev. Gastroenterol. Hepatol. 2016, 13, 412-425. [CrossRef] [PubMed]

70. Ma, J.; Zhou, Q.; Li, H. Gut Microbiota and Nonalcoholic Fatty Liver Disease: Insights on Mechanisms and Therapy. Nutrients 2017, 9, 1124. [CrossRef]

71. Jin, C.J.; Engstler, A.J.; Ziegenhardt, D.; Bischoff, S.C.; Trautwein, C.; Bergheim, I. Loss of lipopolysaccharide-binding protein attenuates the development of diet-induced non-alcoholic fatty liver disease in mice. J. Gastroenterol. Hepatol. 2017, 32, 708-715. [CrossRef]

72. Lawrence, T. The nuclear factor NF-kappaB pathway in inflammation. Cold Spring Harb. Perspect. Biol. 2009, 1, a001651. [CrossRef] 
73. Lancaster, G.I.; Langley, K.G.; Berglund, N.A.; Kammoun, H.L.; Reibe, S.; Estevez, E.; Weir, J.; Mellett, N.A.; Pernes, G.; Conway, J.R.W.; et al. Evidence that TLR4 Is Not a Receptor for Saturated Fatty Acids but Mediates Lipid-Induced Inflammation by Reprogramming Macrophage Metabolism. Cell Metab. 2018, 27, 1096-1110. [CrossRef]

74. Sumida, Y.; Yoneda, M. Current and future pharmacological therapies for NAFLD/NASH. J. Gastroenterol. 2018, 53, 362-376. [CrossRef] [PubMed]

75. Masarone, M.; Rosato, V.; Dallio, M.; Gravina, A.G.; Aglitti, A.; Loguercio, C.; Federico, A.; Persico, M. Role of oxidative stress in the pathogenesis of nonalcoholic fatty liver disease. Oxid. Med. Cell Longev. 2018, 2018, 9547613. [CrossRef] [PubMed]

76. Ucar, F.; Sezer, S.; Erdogan, S.; Akyol, S.; Armutcu, F.; Akyol, O. The relationship between oxidative stress and nonalcoholic fatty liver disease: Its effects on the development of nonalcoholic steatohepatitis. Redox Rep. 2013, 18, 127-133. [CrossRef]

77. Simões, I.C.M.; Fontes, A.; Pinton, P.; Zischka, H.; Wieckowski, M.R. Mitochondria in non-alcoholic fatty liver disease. Int. J. Biochem. Cell Biol. 2018, 95, 93-99. [CrossRef] [PubMed]

78. Pessayre, D.; Berson, A.; Fromenty, B.; Mansouri, A. Mitochondria in steatohepatitis. Semin. Liver Dis. 2001, 21, 57-69. [CrossRef] [PubMed]

79. Letteron, P.; Fromenty, B.; Terris, B.; Degott, C.; Pessayre, D. Acute and chronic hepatic steatosis lead to in vivo lipid peroxidation in mice. J. Hepatol. 1996, 24, 200-208. [CrossRef]

80. Day, C.P.; Saksena, S. Non-alcoholic steatohepatitis: Definitions and pathogenesis. J. Gastroenterol. Hepatol. 2002, 17, S377-S384. [CrossRef] [PubMed]

81. Serfaty, L.; Lemoine, M. Definition and natural history of metabolic steatosis: Clinical aspects of NAFLD, NASH and cirrhosis. Diabetes Metab. 2008, 34, 634-637. [CrossRef]

82. Palmieri, B.; Sblendorio, V. Oxidative stress detection: What for? Part II. Eur. Rev. Med. Pharmacol. Sci. 2007, 11, 27-54. [PubMed]

83. Morgan, M.J.; Liu, Z.G. Crosstalk of reactive oxygen species and NF-kappaB signaling. Cell Res. 2011, 21, 103-115. [CrossRef]

84. Forrester, S.J.; Kikuchi, D.S.; Hernandes, M.S.; Xu, Q.; Griendling, K.K. Reactive Oxygen Species in Metabolic and Inflammatory Signaling. Circ. Res. 2018, 122, 877-902. [CrossRef] [PubMed]

85. Chen, Z.; Tian, R.; She, Z.; Cai, J.; Li, H. Role of oxidative stress in the pathogenesis of nonalcoholic fatty liver disease. Free Radic. Biol. Med. 2020, 152, 116-141. [CrossRef]

86. Begriche, K.; Massart, J.; Robin, M.A.; Bonnet, F.; Fromenty, B. Mitochondrial adaptations and dysfunctions in nonalcoholic fatty liver disease. Hepatology 2013, 58, 1497-1507. [CrossRef]

87. Thuy, L.T.T.; Hai, H.; Kawada, N. Role of cytoglobin, a novel radical scavenger, in stellate cell activation and hepatic fibrosis. Clin. Mol. Hepatol. 2020, 26, 280-293. [CrossRef]

88. Friedman, S.L. Mechanisms of hepatic fibrogenesis. Gastroenterology 2008, 134, 1655-1669. [CrossRef] [PubMed]

89. Il'yasova, D.; Scarbrough, P.; Spasojevic, I. Urinary biomarkers of oxidative status. Clin. Chim. Acta. 2012, 413, 1446-1453. [CrossRef] [PubMed]

90. Montuschi, P.; Barnes, P.J.; Roberts, L.J., 2nd. Isoprostanes: Markers and mediators of oxidative stress. FASEB J. 2004, 18, 1791-1800. [CrossRef] [PubMed]

91. Damiano, S.; Sozio, C.; La Rosa, G.; Santillo, M. NOX-Dependent Signaling Dysregulation in Severe COVID-19: Clues to Effective Treatments. Front. Cell Infect. Microbiol. 2020, 10, 608435. [CrossRef]

92. Loffredo, L.; Carnevale, R.; Cangemi, R.; Angelico, F.; Augelletti, T.; Di Santo, S.; Calabrese, C.M.; Della Volpe, L.; Pignatelli, P.; Perri, L.; et al. NOX2 up-regulation is associated with artery dysfunction in patients with peripheral artery disease. Int. J. Cardiol. 2013, 165, 184-192. [CrossRef]

93. Angelico, F.; Loffredo, L.; Pignatelli, P.; Augelletti, T.; Carnevale, R.; Pacella, A.; Albanese, F.; Mancini, I.; Di Santo, S.; Del Ben, M.; et al. Weight loss is associated with improved endothelial dysfunction via NOX2-generated oxidative stress down-regulation in patients with the metabolic syndrome. Intern. Emerg. Med. 2012, 7, 219-227. [CrossRef] [PubMed]

94. Cangemi, R.; Angelico, F.; Loffredo, L.; Del Ben, M.; Pignatelli, P.; Martini, A.; Violi, F. Oxidative stress-mediated arterial dysfunction in patients with metabolic syndrome: Effect of ascorbic acid. Free Radic. Biol. Med. 2007, 43, 853-859. [CrossRef] [PubMed]

95. Loffredo, L.; Martino, F.; Carnevale, R.; Pignatelli, P.; Catasca, E.; Perri, L.; Calabrese, C.M.; Palumbo, M.M.; Baratta, F.; Del Ben, M.; et al. Obesity and hypercholesterolemia are associated with NOX-2 generated oxidative stress and arterial dysfunction. $J$. Pediatr. 2012, 161, 1004-1009. [CrossRef] [PubMed]

96. Del Ben, M.; Polimeni, L.; Carnevale, R.; Bartimoccia, S.; Nocella, C.; Baratta, F.; Loffredo, L.; Pignatelli, P.; Violi, F.; Angelico, F. NOX2-generated oxidative stress is associated with severity of ultrasound liver steatosis in patients with non-alcoholic fatty liver disease. BMC Gastroenterol. 2014, 14, 81. [CrossRef] [PubMed]

97. Del Ben, M.; Polimeni, L.; Baratta, F.; Bartimoccia, S.; Carnevale, R.; Loffredo, L.; Pignatelli, P.; Violi, F.; Angelico, F. Serum Cytokeratin-18 Is Associated with NOX2-Generated Oxidative Stress in Patients with Nonalcoholic Fatty Liver. Int. J. Hepatol. 2014, 2014, 784985. [CrossRef] [PubMed]

98. Noworyta-Sokołowska, K.; Górska, A.; Gołembiowska, K. LPS-induced oxidative stress and inflammatory reaction in the rat striatum. Pharmacol. Rep. 2013, 65, 863-869. [CrossRef]

99. Dong, Z.; Yuan, Y. Accelerated inflammation and oxidative stress induced by LPS in acute lung injury: Inhibition by ST1926. Int. J. Mol. Med. 2018, 41, 3405-3421. [CrossRef] 
100. Loffredo, L.; Zicari, A.M.; Perri, L.; Carnevale, R.; Nocella, C.; Angelico, F.; Del Ben, M.; Mosca, A.; Zaffina, S.; Panera, N.; et al. Does Nox2 Overactivate in Children with Nonalcoholic Fatty Liver Disease? Antioxid. Redox Signal. 2019, 30, 1325-1330. [CrossRef]

101. Kim, S.Y.; Jeong, J.M.; Kim, S.J.; Seo, W.; Kim, M.H.; Choi, W.M.; Yoo, W.; Lee, J.H.; Shim, Y.R.; Yi, H.S.; et al. Pro-inflammatory hepatic macrophages generate ROS through NADPH oxidase 2 via endocytosis of monomeric TLR4-MD2 complex. Nat. Commun. 2017, 8, 2247. [CrossRef]

102. Buzzetti, E.; Pinzani, M.; Tsochatzis, E.A. The multiple-hit pathogenesis of non-alcoholic fatty liver disease (NAFLD). Metabolism 2016, 65, 1038-1048. [CrossRef] [PubMed]

103. Fang, Y.L.; Chen, H.; Wang, C.L.; Liang, L. Pathogenesis of non-alcoholic fatty liver disease in children and adolescence: From "two hit theory" to "multiple hit model". World J. Gastroenterol. 2018, 24, 2974-2983. [CrossRef] [PubMed]

104. Belfort, R.; Harrison, S.A.; Brown, K.; Darland, C.; Finch, J.; Hardies, J.; Balas, B.; Gastaldelli, A.; Tio, F.; Pulcini, J.; et al. A placebo-controlled trial of pioglitazone in subjects with nonalcoholic steatohepatitis. N. Engl. J. Med. 2006, 355, $2297-2307$. [CrossRef] [PubMed]

105. Sanyal, A.J.; Chalasani, N.; Kowdley, K.V.; McCullough, A.; Diehl, A.M.; Bass, N.M.; Neuschwander-Tetri, B.A.; LaVine, J.E.; Tonascia, J.; Unalp, A.; et al. NASH CRN. Pioglitazone, vitamin E, or placebo for nonalcoholic steatohepatitis. N. Engl. J. Med. 2010, 362, 1675-1685. [CrossRef] [PubMed]

106. Chalasani, N.; Younossi, Z.; Lavine, J.E.; Diehl, A.M.; Brunt, E.M.; Cusi, K.; Charlton, M.; Sanyal, A.J. American Gastroenterological Association, American Association for the Study of Liver Diseases, American College of Gastroenterology The diagnosis and management of non-alcoholic fatty liver disease: Practice guideline by the American Gastroenterological Association, American Association for the Study of Liver Diseases, and American College of Gastroenterology. Gastroenterology 2012, 142, 1592-1609. [PubMed]

107. Rakoski, M.O.; Singal, A.G.; Rogers, M.A.; Conjeevaram, H. Meta-analysis: Insulin sensitizers for the treatment of non-alcoholic steatohepatitis. Aliment. Pharmacol. Ther. 2010, 32, 1211-1221. [CrossRef]

108. Tziomalos, K.; Athyros, V.G.; Karagiannis, A. Non-alcoholic fatty liver disease in type 2 diabetes: Pathogenesis and treatment options. Curr. Vasc. Pharmacol. 2012, 10, 162-172. [CrossRef]

109. Lindor, K.D.; Kowdley, K.V.; Heathcote, E.J.; Harrison, M.E.; Jorgensen, R.; Angulo, P.; Lymp, J.F.; Burgart, L.; Colin, P. Ursodeoxycholic acid for treatment of nonalcoholic steatohepatitis: Results of a randomized trial. Hepatology 2004, $39,770$. [CrossRef]

110. Leuschner, U.F.H.; Lindenthal, B.; Herrmann, G.; Arnold, J.C.; Rössle, M.; Cordes, H.-J.; Zeuzem, S.; Hein, J.; Berg, T.; The NASH Study Group. High-dose ursodeoxycholic acid therapy for nonalcoholic steatohepatitis: A double-blind, randomized, placebo-controlled trial. Hepatology 2010, 52, 472-479. [CrossRef]

111. Dasarathy, S.; Dasarathy, J.; Khiyami, A.; Yerian, L.M.; Sargent, R.; McCullough, A.J. Randomized controlled trial of omega 3 fatty acids in the treatment of non alcoholic steatohepatitis in type 2 diabetes mellitus. Hepatology 2013, 58, 518a.

112. Alam, F.; Islam, M.A.; Mohamed, M.; Ahmad, I.; Kamal, M.A.; Donnelly, R.; Idris, I.; Gan, S.H. Efficacy and Safety of Pioglitazone Monotherapy in Type 2 Diabetes Mellitus: A Systematic Review and Meta-Analysis of Randomised Controlled Trials. Sci. Rep. 2019, 9, 5389. [CrossRef] [PubMed]

113. Lebovitz, H.E. Thiazolidinediones: The Forgotten Diabetes Medications. Curr. Diab. Rep. 2019, 19, 151. [CrossRef] [PubMed]

114. Schernthaner, G.; Currie, C.J.; Schernthaner, G.H. Do We Still Need Pioglitazone for the Treatment of Type 2 Diabetes? A risk-benefit critique in 2013. Diabetes Care 2013, 36, S155-S161. [CrossRef] [PubMed]

115. Vieira, R.; Souto, S.B.; Sánchez-López, E.; Machado, A.L.; Severino, P.; Jose, S.; Santini, A.; Fortuna, A.; García, M.L.; Silva, A.M.; et al. Sugar-Lowering Drugs for Type 2 Diabetes Mellitus and Metabolic Syndrome-Review of Classical and New Compounds: Part-I. Pharmaceuticals 2019, 12, 152. [CrossRef] [PubMed]

116. Tyagi, S.; Gupta, P.; Saini, A.S.; Kaushal, C.; Sharma, S. The peroxisome proliferator-activated receptor: A family of nuclear receptors role in various diseases. J. Adv. Pharm. Technol. Res. 2011, 2, 236-240. [CrossRef] [PubMed]

117. Choi, S.S.; Park, J.; Choi, J.H. Revisiting PPAR $\gamma$ as a target for the treatment of metabolic disorders. BMB Rep. 2014, 47, 599-608. [CrossRef]

118. Corzo, C.; Griffin, P.R. Targeting the Peroxisome Proliferator-Activated Receptor- $\gamma$ to Counter the Inflammatory Milieu in Obesity. Diabetes Metab. J. 2013, 37, 395-403. [CrossRef] [PubMed]

119. Fonseca, V. Effect of thiazolidinediones on body weight in patients with diabetes mellitus. Am. J. Med. 2003, 115, 42S-48S. [CrossRef]

120. Kang, J.G.; Park, C.Y. The actions of PPAR $\gamma$ agonists on the various target organs. Korean J. Obes. 2011, 20, 161-169. [CrossRef]

121. King, A.B.; Armstrong, D.U. Metformin does not prevent the weight gain associated with thiazolidinedione treatment. Endocr. Pract. 2002, 8, 141-142.

122. Kawai, T.; Funae, O.; Shimada, A.; Tabata, M.; Hirata, T.; Atsumi, Y.; Itoh, H. Effects of pretreatment with low-dose metformin on metabolic parameters and weight gain by pioglitazone in Japanese patients with type 2 diabetes. Intern. Med. 2008, 47, 1181-1188. [CrossRef] [PubMed]

123. Musso, G.; Cassader, M.; Paschetta, E.; Gambino, R. Thiazolidinediones and Advanced Liver Fibrosis in Nonalcoholic Steatohepatitis: A Meta-analysis. JAMA Intern. Med. 2017, 177, 633-640. [CrossRef] [PubMed] 
124. He, L.; Liu, X.; Wang, L.; Yang, Z. Thiazolidine Effect of pioglitazone on biochemical indicesdiones for nonalcoholic steatohepatitis: A meta-analysis of randomized clinical trials. Medicine 2016, 95, e4947. [CrossRef] [PubMed]

125. Bril, F.; Kalavalapalli, S.; Clark, V.C.; Lomonaco, R.; Soldevila-Pico, C.; Liu, I.C.; Orsak, B.; Tio, F.; Cusi, K. Response to Pioglitazone in Patients With Nonalcoholic Steatohepatitis With vs Without Type 2 Diabetes. Clin. Gastroenterol. Hepatol. 2018, 16, 558-566. [CrossRef]

126. Yuan, G.J.; Zhang, M.L.; Gong, Z.J. Effects of PPARg agonist pioglitazone on rat hepatic fibrosis. World J. Gastroenterol. 2004, 10, 1047-1051. [CrossRef] [PubMed]

127. Adorini, L.; Pruzanski, M.; Shapiro, D. Farnesoid X receptor targeting to treat nonalcoholic steatohepatitis. Drug Discov. Today 2012, 17, 988-997. [CrossRef] [PubMed]

128. Shah, R.A.; Kowdley, K.V. Obeticholic acid for the treatment of nonalcoholic steatohepatitis. Expert Rev. Gastroenterol. Hepatol. 2020, 14, 311-321. [CrossRef]

129. Verbeke, L.; Mannaerts, I.; Schierwagen, R.; Govaere, O.; Klein, S.; Vander Elst, I.; Windmolders, P.; Farre, R.; Wenes, M.; Mazzone, M.; et al. FXR agonist obeticholic acid reduces hepatic inflammation and fibrosis in a rat model of toxic cirrhosis. Sci. Rep. 2016, 6, 33453. [CrossRef]

130. Fiorucci, S.; Antonelli, E.; Rizzo, G.; Renga, B.; Mencarelli, A.; Riccardi, L.; Orlandi, S.; Pellicciari, R.; Morelli, A. The nuclear receptor SHP mediates inhibition of hepatic stellate cells by FXR and protects against liver fibrosis. Gastroenterology 2004, 127, 1497-1512. [CrossRef]

131. Li, T.; Francl, J.M.; Boehme, S.; Chiang, J.Y. Regulation of cholesterol and bile acid homeostasis by the cholesterol $7 \alpha-$ hydroxylase/steroid response element-binding protein 2/microRNA-33a axis in mice. Hepatology 2013, 58, 1111-1121. [CrossRef]

132. Pellicciari, R.; Costantino, G.; Camaioni, E.; Sadeghpour, B.M.; Entrena, A.; Willson, T.M.; Fiorucci, S.; Clerici, C.; Gioiello, A. Bile Acid Derivatives as Ligands of the Farnesoid X Receptor. Synthesis, Evaluation, and Structure-Activity Relationship of a Series of Body and Side Chain Modified Analogues of Chenodeoxycholic Acid. J. Med. Chem. 2004, 47, 4559-4569. [CrossRef] [PubMed]

133. Mudaliar, S.; Henry, R.R.; Sanyal, A.J.; Morrow, L.; Marschall, H.U.; Kipnes, M.; Adorini, L.; Sciacca, C.I.; Clopton, P.; Castelloe, E.; et al. Efficacy and Safety of the Farnesoid X Receptor Agonist Obeticholic Acid in Patients With Type 2 Diabetes and Nonalcoholic Fatty Liver Disease. Gastroenterology 2013, 145, 574-582. [CrossRef] [PubMed]

134. Hameed, B.; Terrault, N.A.; Gill, R.M.; Loomba, R.; Chalasani, N.; Hoofnagle, J.H.; Van Natta, M.L.; The NASH Clinical Research Network. Clinical and metabolic effects associated with weight changes and obeticholic acid in non-alcoholic steatohepatitis. Aliment. Pharmacol. Ther. 2018, 47, 645-656. [CrossRef] [PubMed]

135. Hindson, J. Obeticholic acid for the treatment of NASH. Nat. Rev. Gastroenterol. Hepatol. 2020, 17, 66. [CrossRef] [PubMed]

136. Berger, J.; Moller, D.E. The mechanisms of action of PPARs. Annu. Rev. Med. 2002, 53, 409-435. [CrossRef] [PubMed]

137. Connolly, J.J.; Ooka, K.; Lim, J.K. Future Pharmacotherapy for Non-alcoholic Steatohepatitis (NASH): Review of Phase 2 and 3 Trials. J. Clin. Transl. Hepatol. 2018, 6, 264-275. [CrossRef] [PubMed]

138. Pawlak, M.; Lefebvre, P.; Staels, B. Molecular mechanism of PPARalpha action and its impact on lipid metabolism, inflammation and fibrosis in non-alcoholic fatty liver disease. J. Hepatol. 2015, 62, 720-733. [CrossRef] [PubMed]

139. Musso, G.; Gambino, R.; Cassader, M.; Pagano, G. A meta-analysis of randomized trials for the treatment of nonalcoholic fatty liver disease. Hepatology 2010, 52, 79-104. [CrossRef]

140. Bojic, L.A.; Huff, M.W. Peroxisome proliferator-activated receptor $\delta:$ A multifaceted metabolic player. Curr. Opin. Lipidol. 2013, 24, 171-177. [CrossRef]

141. Karpe, F.; Ehrenborg, E.E. PPARdelta in humans: Genetic and pharmacological evidence for a significant metabolic function. Curr. Opin. Lipidol. 2009, 20, 333-336. [CrossRef]

142. Coll, T.; Rodrïguez-Calvo, R.; Barroso, E.; Serrano, L.; Eyre, E.; Palomer, X.; Vázquez-Carrera, M. Peroxisome proliferator-activated receptor (PPAR) beta/delta: A new potential therapeutic target for the treatment of metabolic syndrome. Curr. Mol. Pharmacol. 2009, 2, 46-55. [CrossRef]

143. Risérus, U.; Sprecher, D.; Johnson, T.; Olson, E.; Hirschberg, S.; Liu, A.; Fang, Z.; Hegde, P.; Richards, D.; Sarov-Blat, L.; et al. Activation of Peroxisome Proliferator-Activated Receptor (PPAR) $\delta$ Promotes Reversal of Multiple Metabolic Abnormalities, Reduces Oxidative Stress, and Increases Fatty Acid Oxidation in Moderately Obese Men. Diabetes 2008, 57, 332-339. [CrossRef] [PubMed]

144. Ratziu, V.; Harrison, S.A.; Francque, S.; Bedossa, P.; Lehert, P.; Serfaty, L.; Romero-Gomez, M.; Boursier, J.; Abdelmalek, M.; Caldwell, S.; et al. Elafibranor, an Agonist of the Peroxisome Proliferator-Activated Receptor- $\alpha$ and $-\delta$, Induces Resolution of Nonalcoholic Steatohepatitis Without Fibrosis Worsening. Gastroenterology 2016, 150, 1147-1159. [CrossRef] [PubMed]

145. Briand, F.; Heymes, C.; Bonada, L.; Angles, T.; Charpentier, J.; Branchereau, M.; Brousseau, E.; Quinsat, M.; Fazilleau, N.; Burcelin, R.; et al. A 3-week nonalcoholic steatohepatitis mouse model shows elafibranor benefits on hepatic inflammation and cell death. Clin. Transl. Sci. 2020, 13, 529-538. [CrossRef] [PubMed]

146. Staels, B.; Rubenstrunk, A.; Noel, B.; Rigou, G.; Delataille, P.; Millatt, L.J.; Baron, M.; Lucas, A.; Tailleux, A.; Hum, D.W.; et al. Hepatoprotectiveeffects of the dual peroxisome proliferator-activated receptor alpha/delta agonist, GFT505, in rodent models of nonalcoholic fatty liver disease/nonalcoholic steatohepatitis. Hepatology 2013, 58, 1941-1952. [CrossRef] 
147. Tølbøl, K.S.; Kristiansen, M.N.; Hansen, H.H.; Veidal, S.S.; Rigbolt, K.T.; Gillum, M.P.; Jelsing, J.; Vrang, N.; Feigh, M. Metabolic and hepatic effects of liraglutide, obeticholic acid and elafibranor in diet-induced obese mouse models of biopsy-confirmed nonalcoholic steatohepatitis. World J. Gastroenterol. 2018, 24, 179-194. [CrossRef]

148. Baandrup Kristiansen, M.N.; Veidal, S.S.; Christoffersen, C.; Feigh, M.; Vrang, N.; Roth, J.D.; Erickson, M.; Adorini, L.; Jelsing, J. Validity of biopsy-based drug effects in a diet-induced obese mouse model of biopsy-confirmed NASH. BMC Gastroenterol. 2019, 19, 228. [CrossRef] [PubMed]

149. Briand, F.; Maupoint, J.; Brousseau, E.; Breyner, N.; Bouchet, M.; Costard, C.; Leste-Lasserre, T.; Petitjean, M.; Chen, L.; Chabrat, A.; et al. Elafibranor improves diet-induced nonalcoholic steatohepatitis associated with heart failure with preserved ejection fraction in Golden Syrian hamsters. Metabolism 2021, 117, 154707. [CrossRef] [PubMed]

150. Cariou, B.; Hanf, R.; Lambert-Porcheron, S.; Zaïr, Y.; Sauvinet, V.; Noël, B.; Flet, L.; Vidal, H.; Staels, B.; Laville, M. Dual Peroxisome Proliferator-Activated Receptor $\alpha / \delta$ Agonist GFT505 Improves Hepatic and Peripheral Insulin Sensitivity in Abdominally Obese Subjects. Diabetes Care 2013, 36, 2923-2930. [CrossRef] [PubMed]

151. Cariou, B.; Zaïr, Y.; Staels, B.; Bruckert, E. Effects of the new dual PPAR alpha/delta agonist GFT505 on lipid and glucose homeostasis in abdominally obese patients with combined dyslipidemia or impaired glucose metabolism. Diabetes Care 2011, 34, 2008-2014. [CrossRef]

152. Jeong, S.W. Nonalcoholic Fatty Liver Disease: A Drug Revolution Is Coming. Diabetes Metab. J. 2020, 44, 640-657. [CrossRef]

153. Iruarrizaga-Lejarreta, M.; Varela-Rey, M.; Fernández-Ramos, D.; Martínez-Arranz, I.; Delgado, T.C.; Simon, J.; Juan, V.G.-D.; Delacruz-Villar, L.; Azkargorta, M.; Lavin, J.L.; et al. Role of Aramchol in steatohepatitis and fibrosis in mice. Hepatol. Commun. 2017, 1, 911-927. [CrossRef] [PubMed]

154. Dobrzyn, A.; Ntambi, J.M. Stearoyl-CoA desaturase as a new drug target for obesity treatment. Obes. Rev. 2005, 6, 169-174. [CrossRef]

155. Dobrzyn, P.; Dobrzyn, A.; Miyazaki, M.; Cohen, P.; Asilmaz, E.; Hardie, D.G.; Friedman, J.M.; Ntambi, J.M. Stearoyl-CoA desaturase 1 deficiency increases fatty acid oxidation by activating AMP-activated protein kinase in liver. Proc. Natl. Acad. Sci. USA 2004, 101, 6409-6414. [CrossRef]

156. Goldiner, I.; van der Velde, A.E.; Vandenberghe, K.E.; van Wijland, M.A.; Halpern, Z.; Gilat, T.; Konikoff, F.M.; Veldman, R.J.; Groen, A.K. ABCA1-dependent but apoA-I-independent cholesterol efflux mediated by fatty acid-bile acid conjugates (FABACs). Biochem. J. 2006, 396, 529-536. [CrossRef] [PubMed]

157. Safadi, R.; Konikoff, F.M.; Mahamid, M.; Zelber-Sagi, S.; Halpern, M.; Gilat, T.; Oren, R. The Fatty Acid-Bile Acid Conjugate Aramchol Reduces Liver Fat Content in Patients with Nonalcoholic Fatty Liver Disease. Clin. Gastroenterol. Hepatol. 2014, 12, 2085-2091. [CrossRef] [PubMed]

158. Gentilella, R.; Pechtner, V.; Corcos, A.; Consoli, A. Glucagon-like peptide-1 receptor agonists in type 2 diabetes treatment: Are they all the same? Diabetes Metab. Res. Rev. 2019, 35, e3070. [CrossRef]

159. Seppa, K.; Toots, M.; Reimets, R.; Jagomäe, T.; Koppel, T.; Pallase, M.; Hasselholt, S.; Krogsbæk Mikkelsen, M.; Randel Nyengaard, J.; Vasar, E.; et al. GLP-1 receptor agonist liraglutide has a neuroprotective effect on an aged rat model of Wolfram syndrome. Sci. Rep. 2019, 9, 15742. [CrossRef] [PubMed]

160. Kristensen, S.L.; Rørth, R.; Jhund, P.S.; Docherty, K.F.; Sattar, N.; Preiss, D.; Køber, L.; Petrie, M.C.; McMurray, J.J.V. Cardiovascular, mortality, and kidney outcomes with GLP-1 receptor agonists in patients with type 2 diabetes: A systematic review and meta-analysis of cardiovascular outcome trials. Lancet Diabetes Endocrinol. 2019, 7, 776-785. [CrossRef]

161. Greiner, T.U.; Bäckhed, F. Microbial regulation of GLP-1 and L-cell biology. Mol. Metab. 2016, 5, 753-758. [CrossRef]

162. Meloni, A.R.; DeYoung, M.B.; Lowe, C.; Parkes, D.G. GLP-1 receptor activated insulin secretion from pancreatic $\beta$-cells: Mechanism and glucose dependence. Diabetes Obes. Metab. 2013, 15, 15-27. [CrossRef] [PubMed]

163. Michałowska, J.; Miller-Kasprzak, E.; Bogdański, P. Incretin Hormones in Obesity and Related Cardiometabolic Disorders: The Clinical Perspective. Nutrients 2021, 13, 351. [CrossRef] [PubMed]

164. Armstrong, M.J.; Gaunt, P.; Aithal, G.P.; Barton, D.; Hull, D.; Parker, R.; Hazlehurst, J.M.; Guo, K.; Abouda, G.; Aldersley, M.A.; et al. Liraglutide safety and efficacy in patients with non-alcoholic steatohepatitis (LEAN): A multicentre, double-blind, randomised, placebo-controlled phase 2 study. Lancet 2016, 387, 679-690. [CrossRef]

165. DeFronzo, R.; Ratner, R.; Han, J.; Kim, D.; Fineman, M.; Baron, A. Effects of exenatide (exendin-4) on glycaemic control and weight over 30 weeks in metformin-treated patients with type 2 diabetes. Diabetes Care 2005, 28, 1092-1100. [CrossRef] [PubMed]

166. Crane, J.; McGowan, B. The GLP-1 agonist, liraglutide, as a pharmacotherapy for obesity. Ther. Adv. Chronic Dis. 2016, 7, 92-107. [CrossRef]

167. Nuffer, W.A.; Trujillo, J.M. Liraglutide: A New Option for the Treatment of Obesity. Pharmacotherapy 2015, 35, 926-934. [CrossRef] [PubMed]

168. Davies, M.J.; Aronne, L.J.; Caterson, I.D.; Thomsen, A.B.; Jacobsen, P.B.; Marso, S.P. Liraglutide and cardiovascular outcomes in adults with overweight or obesity: A post hoc analysis from SCALE randomized controlled trials. Diabetes Obes. Metab. 2018, 20, 734-739. [CrossRef] [PubMed]

169. Adams, J.M.; Pei, H.; Sandoval, D.A.; Seeley, R.J.; Chang, R.B.; Liberles, S.D.; Olson, D.P. Liraglutide Modulates Appetite and Body Weight Through Glucagon-Like Peptide 1 Receptor-Expressing Glutamatergic Neurons. Diabetes 2018, 67, 1538-1548. [CrossRef] [PubMed] 
170. Ohki, T.; Isogawa, A.; Iwamoto, M.; Ohsugi, M.; Yoshida, H.; Toda, N.; Tagawa, K.; Omata, M.; Koike, K. The effectiveness of liraglutide in nonalcoholic fatty liver disease patients with type 2 diabetes mellitus compared to sitagliptin and pioglitazone. Sci. World J. 2012, 2012, 496453. [CrossRef]

171. Mantovani, A.; Petracca, G.; Beatrice, G.; Csermely, A.; Lonardo, A.; Targher, G. Glucagon-Like Peptide-1 Receptor Agonists for Treatment of Nonalcoholic Fatty Liver Disease and Nonalcoholic Steatohepatitis: An Updated Meta-Analysis of Randomized Controlled Trials. Metabolites 2021, 11, 73. [CrossRef] [PubMed]

172. Flisiak-Jackiewicz, M.; Lebensztejn, D.M. Update on pathogenesis, diagnostics and therapy of nonalcoholic fatty liver disease in children. Clin. Exp. Hepatol. 2019, 5, 11-21. [CrossRef] [PubMed]

173. Kapodistria, K.; Tsilibary, E.P.; Kotsopoulou, E.; Moustardas, P.; Kitsiou, P. Liraglutide, a human glucagon-like peptide-1 analogue, stimulates AKT-dependent survival signalling and inhibits pancreatic $\beta$-cell apoptosis. J. Cell Mol. Med. 2018, 22, $2970-2980$. [CrossRef] [PubMed]

174. Yamazaki, S.; Satoh, H.; Watanabe, T. Liraglutide enhances insulin sensitivity by activating AMP-activated protein kinase in male Wistar rats. Endocrinology 2014, 155, 3288-3301. [CrossRef] [PubMed]

175. Mells, J.E.; Fu, P.P.; Sharma, S.; Olson, D.; Cheng, L.; Handy, J.A.; Saxena, N.K.; Sorescu, D.; Anania, F.A. Glp-1 analog, liraglutide, ameliorates hepatic steatosis and cardiac hypertrophy in C57BL/6J mice fed a Western diet. Am. J. Physiol. Gastrointest. Liver Physiol. 2012, 302, G225-G235. [CrossRef] [PubMed]

176. He, Q.; Sha, S.; Sun, L.; Zhang, J.; Dong, M. GLP-1 analogue improves hepatic lipid accumulation by inducing autophagy via AMPK/mTOR pathway. Biochem. Biophys. Res. Commun. 2016, 476, 196-203. [CrossRef]

177. Chalasani, N.; Younossi, Z.; LaVine, J.E.; Diehl, A.M.; Brunt, E.M.; Cusi, K.; Sanyal, A.J. The diagnosis and management of non-alcoholic fatty liver disease: Practice guideline by the American Association for the Study of Liver Diseases, American College of Gastroenterology, and the American Gastroenterological Association. Hepatology 2012, 55, 2005-2023. [CrossRef]

178. Matteoni, C.A.; Younossi, Z.M.; Gramlich, T.; Boparai, N.; Liu, Y.C.; McCullough, A.J. Nonalcoholic fatty liver disease: A spectrum of clinical and pathological severity. Gastroenterology 1999, 116, 1413-1419. [CrossRef]

179. Nelson, C.H.; Etchevers, K.; Yi, S.; Breckenridge, D.; Hepner, M.; Patel, U.; Ling, J.; Mathias, A. Pharmacokinetics, Safety, and Tolerability of Selonsertib, an Apoptosis Signal-Regulating Kinase 1 (ASK1) Inhibitor, Following First-in-Human Single and Multiple Ascending Doses in Healthy Subjects. Clin. Pharmacokinet. 2020, 59, 1109-1117. [CrossRef]

180. Budas, G.; Karnik, S.; Jonnson, T.; Shafizadeh, T.; Watkins, S.; Breckenridge, D.; Breckenridge, D.; Tumas, D. Reduction of liver steatosis and fibrosis with an ASK1 inhibitor in a murine model of NASH is accomplished by improvements in cholesterol, bile acid and lipid metabolism. J. Hepatol. 2016, 64, S170. [CrossRef]

181. Yamamoto, E.; Dong, Y.-F.; Kataoka, K.; Yamashita, T.; Tokutomi, Y.; Matsuba, S.; Ichijo, H.; Ogawa, H.; Kim-Mitsuyama, S. Olmesartan prevents cardiovascular injury and hepatic steatosis in obesity and diabetes, accompanied by apoptosis signal regulating kinase-1 inhibition. Hypertension 2008, 52, 573-580. [CrossRef]

182. Wang, P.-X.; Ji, Y.-X.; Zhang, X.-J.; Zhao, L.-P.; Yan, Z.-Z.; Zhang, P.; Shen, L.-J.; Yang, X.; Fang, J.; Tian, S.; et al. Targeting CASP8 and FADD-like apoptosis regulator ameliorates nonalcoholic steatohepatitis in mice and nonhuman primates. Nat. Med. 2017, 23, 439-449. [CrossRef] [PubMed]

183. Loomba, R.; Lawitz, E.; Mantry, P.S.; Jayakumar, S.; Caldwell, S.H.; Arnold, H.; Diehl, A.M.; Djedjos, C.S.; Han, L.; Myers, R.P.; et al. The ASK1 inhibitor selonsertib in patients with nonalcoholic steatohepatitis: A randomized, phase 2 trial. Hepatology 2018, 67, 549-559. [CrossRef] [PubMed]

184. Harrison, S.A.; Wong, V.W.; Okanoue, T.; Bzowej, N.; Vuppalanchi, R.; Younes, Z.; Kohli, A.; Sarin, S.; Caldwell, S.H.; Alkhouri, N.; et al. Selonsertib for patients with bridging fibrosis or compensated cirrhosis due to NASH: Results from randomized phase III STELLAR trials. J. Hepatol. 2020, 73, 26-39. [CrossRef] [PubMed]

185. Dickson, I. No anti-fibrotic effect of selonsertib in NASH. Nat. Rev. Gastroenterol. Hepatol. 2020, 17, 260. [CrossRef] [PubMed]

186. Puente, A.; Fortea, J.I.; Cabezas, J.; Arias Loste, M.T.; Iruzubieta, P.; Llerena, S.; Huelin, P.; Fábrega, E.; Crespo, J. LOXL2-A New Target in Antifibrogenic Therapy? Int. J. Mol. Sci. 2019, 20, 1634. [CrossRef]

187. Cai, L.; Xiong, X.; Kong, X.; Xie, J. The Role of the Lysyl Oxidases in Tissue Repair and Remodeling: A Concise Review. Tissue Eng. Regen. Med. 2017, 14, 15-30. [CrossRef]

188. Rodriguez, H.M.; Vaysberg, M.; Mikels, A.; McCauley, S.; Velayo, A.C.; Garcia, C.; Smith, V. Modulation of lysyl oxidase-like 2 enzymatic activity by an allosteric antibody inhibitor. J. Biol. Chem. 2010, 285, 20964-20974. [CrossRef] [PubMed]

189. Lipson, K.E.; Wong, C.; Teng, Y.; Spong, S. CTGF is a central mediator of tissue remodeling and fibrosis and its inhibition can reverse the process of fibrosis. Fibrogenesis Tissue Repair 2012, 5, S24. [CrossRef] [PubMed]

190. Harrison, S.A.; Abdelmalek, M.F.; Caldwell, S.; Shiffman, M.L.; Diehl, A.M.; Ghalib, R.; Lawitz, E.J.; Rockey, D.C.; Schall, R.A.; Jia, C.; et al. Simtuzumab Is Ineffective for Patients With Bridging Fibrosis or Compensated Cirrhosis Caused by Nonalcoholic Steatohepatitis. Gastroenterology 2018, 155, 1140-1153. [CrossRef]

191. Marra, F.; Tacke, F. Roles for chemokines in liver disease. Gastroenterology 2014, 147, 577-594. [CrossRef] [PubMed]

192. Kim, B.M.; Abdelfattah, A.M.; Vasan, R.; Fuchs, B.C.; Choi, M.Y. Hepatic stellate cells secrete Ccl5 to induce hepatocyte steatosis. Sci. Rep. 2018, 8, 7499. [CrossRef] [PubMed]

193. Roh, Y.S.; Seki, E. Chemokines and chemokine receptors in the development of NAFLD. Adv. Exp. Med. Biol. 2018, 1061, 45-53. [PubMed] 
194. Friedman, S.; Sanyal, A.; Goodman, Z.; Lefebvre, E.; Gottwald, M.; Fischer, L.; Ratziu, V. Efficacy and safety study of cenicriviroc for the treatment of non-alcoholic steatohepatitis in adult subjects with liver fibrosis: CENTAUR Phase $2 \mathrm{~b}$ study design. Contemp. Clin. Trials 2016, 47, 356-365. [CrossRef] [PubMed]

195. Tacke, F. Cenicriviroc for the treatment of non-alcoholic steatohepatitis and liver fibrosis. Expert Opin. Investig. Drugs 2018, 27, 301-311. [CrossRef] [PubMed]

196. Friedman, S.L.; Ratziu, V.; Harrison, S.A.; Abdelmalek, M.F.; Aithal, G.P.; Caballeria, J.; Francque, S.; Farrell, G.; Kowdley, K.V.; Craxi, A.; et al. A randomized, placebo-controlled trial of cenicriviroc for treatment of nonalcoholic steatohepatitis with fibrosis. Hepatology 2018, 67, 1754-1767. [CrossRef] [PubMed]

197. Anstee, Q.M.; Neuschwander-Tetri, B.A.; Wong, V.W.; Abdelmalek, M.F.; Younossi, Z.M.; Yuan, J.; Pecoraro, M.L.; Seyedkazemi, S.; Fischer, L.; Bedossa, P.; et al. Cenicriviroc for the treatment of liver fibrosis in adults with nonalcoholic steatohepatitis: AURORA Phase 3 study design. Contemp. Clin. Trials 2020, 89, 105922. [CrossRef] [PubMed]

198. Boutari, C.; Perakakis, N.; Mantzoros, C.S. Association of Adipokines with Development and Progression of Nonalcoholic Fatty Liver Disease. Endocrinol. Metab. 2018, 33, 33-43. [CrossRef]

199. Tsochatzis, E.; Papatheodoridis, G.V.; Archimandritis, A.J. The evolving role of leptin and adiponectin in chronic liver diseases. Am. J. Gastroenterol. 2006, 101, 2629-2640. [CrossRef]

200. Polyzos, S.A.; Kountouras, J.; Mantzoros, C.S. Leptin in nonalcoholic fatty liver disease: A narrative review. Metabolism 2015, 64, 60-78. [CrossRef]

201. Senateş, E.; Colak, Y.; Yeşil, A.; Coşkunpinar, E.; Sahin, O.; Kahraman, O.T.; Erkalma Şenateş, B.; Tuncer, I. Circulating resistin is elevated in patients with non-alcoholic fatty liver disease and is associated with steatosis, portal inflammation, insulin resistance and nonalcoholic steatohepatitis scores. Minerva Med. 2012, 103, 369-376. [PubMed]

202. Pagano, C.; Soardo, G.; Pilon, C.; Milocco, C.; Basan, L.; Milan, G.; Donnini, D.; Faggian, D.; Mussap, M.; Plebani, M.; et al. Increased serum resistin in nonalcoholic fatty liver disease is related to liver disease severity and not to insulin resistance. J. Clin. Endocrinol. Metab. 2006, 91, 1081-1086. [CrossRef]

203. Genc, H.; Dogru, T.; Kara, M.; Tapan, S.; Ercin, C.N.; Acikel, C.; Karslioglu, Y.; Bagci, S. Association of plasma visfatin with hepatic and systemic inflammation in nonalcoholic fatty liver disease. Ann. Hepatol. 2013, 12, 548-555. [CrossRef]

204. Jamali, R.; Arj, A.; Razavizade, M.; Aarabi, M.H. Prediction of Nonalcoholic Fatty Liver Disease Via a Novel Panel of Serum Adipokines. Medicine 2016, 95, e2630. [CrossRef] [PubMed]

205. Buechler, C.; Wanninger, J.; Neumeier, M. Adiponectin, a key adipokine in obesity related liver diseases. World J. Gastroenterol. 2011, 17, 2801-2811. [PubMed]

206. Xu, A.; Wang, Y.; Keshaw, H.; Xu, L.Y.; Lam, K.S.; Cooper, G.J. The fat-derived hormone adiponectin alleviates alcoholic and nonalcoholic fatty liver diseases in mice. J. Clin. Investig. 2003, 112, 91-100. [CrossRef] [PubMed]

207. Kaser, S.; Moschen, A.; Cayon, A.; Kaser, A.; Crespo, J.; Pons-Romero, F.; Ebenbichler, C.F.; Patsch, J.R.; Tilg, H. Adiponectin and its receptors in non-alcoholic steatohepatitis. Gut 2005, 54, 117-121. [CrossRef] [PubMed]

208. Polyzos, S.A.; Kountouras, J.; Anastasilakis, A.D.; Geladari, E.V.; Mantzoros, C.S. Irisin in patients with nonalcoholic fatty liver disease. Metabolism 2014, 63, 207-217. [CrossRef]

209. Hu, J.; Ke, Y.; Wu, F.; Liu, S.; Ji, C.; Zhu, X.; Zhang, Y. Circulating Irisin Levels in Patients with Nonalcoholic Fatty Liver Disease: A Systematic Review and Meta-Analysis. Gastroenterol. Res. Pract. 2020, 2020, 8818191. [CrossRef]

210. Li, Y.; Hai, J.; Li, L.; Chen, X.; Peng, H.; Cao, M.; Zhang, Q. Administration of ghrelin improves inflammation, oxidative stress, and apoptosis during and after non-alcoholic fatty liver disease development. Endocrine 2013, 43, 376-386. [CrossRef]

211. Zhang, S.R.; Fan, X.M. Ghrelin-ghrelin O-acyltransferase system in the pathogenesis of nonalcoholic fatty liver disease. World J. Gastroenterol. 2015, 21, 3214-3222. [CrossRef]

212. Shadid, S.; Jensen, M.D. Effect of pioglitazone on biochemical indices of non-alcoholic fatty liver disease in upper body obesity. Clin. Gastroenterol. Hepatol. 2003, 1, 384-387. [CrossRef]

213. Aithal, G.P.; Thomas, J.A.; Kaye, P.V.; Lawson, A.; Ryder, S.D.; Spendlove, I.; Austin, A.S.; Freeman, J.G.; Morgan, L.; Webber, J. Randomized, placebo-controlled trial of pioglitazone in nondiabetic subjects with nonalcoholic steatohepatitis. Gastroenterology 2008, 135, 1176-1184. [CrossRef] [PubMed]

214. Neuschwander-Tetri, B.A.; Loomba, R.; Sanyal, A.J.; Lavine, J.E.; Van Natta, M.L.; Abdelmalek, M.F.; Chalasani, N.; Dasarathy, S.; Diehl, A.M.; Hameed, B.; et al. Farnesoid X nuclear receptor ligand obeticholic acid for non-cirrhotic, non-alcoholic steatohepatitis (FLINT): A multicentre, randomised, placebo-controlled trial. Lancet 2015, 385, 956-965. [CrossRef]

215. Younossi, Z.M.; Ratziu, V.; Loomba, R.; Rinella, M.; Anstee, Q.M.; Goodman, Z.; Bedossa, P.; Geier, A.; Beckebaum, S.; Newsome, P.N.; et al. Obeticholic acid for the treatment of non-alcoholic steatohepatitis: Interim analysis from a multicentre, randomised, placebo-controlled phase 3 trial [published correction appears in Lancet. Lancet 2019, 394, 2184-2196. [CrossRef]

216. Shiomi, M.; Tanaka, Y.; Takada, T.; Otori, K. Determining whether the effect of liraglutide on non-alcoholic fatty liver disease depends on reductions in the body mass index. JGH Open 2020, 4, 995-1001. [CrossRef]

217. Armstrong, M.J.; Hull, D.; Guo, K.; Barton, D.; Hazlehurst, J.M.; Gathercole, L.L.; Nasiri, M.; Yu, J.; Gough, S.C.; Newsome, P.N.; et al. Glucagon-like peptide 1 decreases lipotoxicity in non-alcoholic steatohepatitis. J. Hepatol. 2016, 64, 399-408. [CrossRef]

218. Muir, A.J.; Levy, C.; Janssen, H.L.A.; Montano-Loza, A.J.; Shiffman, M.L.; Caldwell, S.; Luketic, V.; Ding, D.; Jia, C.; McColgan, B.J.; et al. Simtuzumab for Primary Sclerosing Cholangitis: Phase 2 Study Results with Insights on the Natural History of the Disease. Hepatology 2019, 69, 684-698. [CrossRef] [PubMed] 
219. Sanyal, A.J.; Harrison, S.A.; Ratziu, V.; Abdelmalek, M.F.; Diehl, A.M.; Caldwell, S.; Shiffman, M.L.; Aguilar Schall, R.; Jia, C.; McColgan, B.; et al. The Natural History of Advanced Fibrosis Due to Nonalcoholic Steatohepatitis: Data from the Simtuzumab Trials. Hepatology 2019, 70, 1913-1927. [CrossRef] [PubMed]

220. Pagano, C.; Soardo, G.; Esposito, W.; Fallo, F.; Basan, L.; Donnini, D.; Federspil, G.; Sechi, L.A.; Vettor, R. Plasma adiponectin is decreased in nonalcoholic fatty liver disease. Eur. J. Endocrinol. 2005, 152, 113-118. [CrossRef] [PubMed]

221. Arvaniti, V.A.; Thomopoulos, K.C.; Tsamandas, A.; Makri, M.; Psyrogiannis, A.; Vafiadis, G.; Assimakopoulos, S.F.; LabropoulouKaratza, C. Serum adiponectin levels in different types of non alcoholic liver disease. Correlation with steatosis, necroinflammation and fibrosis. Acta Gastroenterol. Belg. 2008, 71, 355-360. [PubMed]

222. Musso, G.; Gambino, R.; Durazzo, M.; Biroli, G.; Carello, M.; Fagà, E.; Pacini, G.; De Michieli, F.; Rabbione, L.; Premoli, A.; et al. Adipokines in NASH: Postprandial lipid metabolism as a link between adiponectin and liver disease. Hepatology 2005, 42, 1175-1183. [CrossRef] [PubMed]

223. Garinis, G.A.; Fruci, B.; Mazza, A.; De Siena, M.; Abenavoli, S.; Gulletta, E.; Ventura, V.; Greco, M.; Abenavoli, L.; Belfiore, A. Metformin versus dietary treatment in nonalcoholic hepatic steatosis: A randomized study. Int. J. Obes. 2010, 34, 1255-1264. [CrossRef] [PubMed]

224. Ryan, M.J.; Dudash, H.J.; Docherty, M.; Geronilla, K.B.; Baker, B.A.; Haff, G.G.; Cutlip, R.G.; Alway, S.E. Vitamin E and C supplementation reduces oxidative stress, improves antioxidant enzymes and positive muscle work in chronically loaded muscles of aged rats. Exp. Gerontol. 2010, 45, 882-895. [CrossRef] [PubMed]

225. Violi, F.; Cangemi, R. Pioglitazone, vitamin E, or placebo for nonalcoholic steatohepatitis. N. Engl. J. Med. 2010, 363 , 1185-1186.

226. Balmer, M.L.; Siegrist, K.; Zimmermann, A.; Dufour, J.F. Effects of ursodeoxycholic acid in combination with vitamin E on adipokines and apoptosis in patients with nonalcoholic steatohepatitis. Liver Int. 2009, 29, 1184-1188. [CrossRef] [PubMed]

227. Bril, F.; Biernacki, D.M.; Kalavalapalli, S.; Lomonaco, R.; Subbarayan, S.K.; Lai, J.; Tio, F.; Suman, A.; Orsak, B.K.; Hecht, J.; et al. Role of Vitamin E for Nonalcoholic Steatohepatitis in Patients with Type 2 Diabetes: A Randomized Controlled Trial. Diabetes Care 2019, 42, 1481-1488. [CrossRef] [PubMed]

228. You, M.; Considine, R.V.; Leone, T.C.; Kelly, D.P.; Crabb, D.W. Role of adiponectin in the protective action of dietary saturated fat against alcoholic fatty liver in mice. Hepatology 2005, 42, 568-577. [CrossRef] [PubMed]

229. Otabe, S.; Yuan, X.; Fukutani, T.; Wada, N.; Hashinaga, T.; Nakayama, H.; Hirota, N.; Kojima, M.; Yamada, K. Overexpression of human adiponectin in transgenic mice results in suppression of fat accumulation and prevention of premature death by high-calorie diet. Am. J. Physiol. Endocrinol. Metab. 2007, 293, E210-E218. [CrossRef]

230. Saxena, N.K.; Fu, P.P.; Nagalingam, A.; Wang, J.; Handy, J.; Cohen, C.; Tighiouart, M.; Sharma, D.; Anania, F.A. Adiponectin modulates $\mathrm{C}$-jun $\mathrm{N}$-terminal kinase and mammalian target of rapamycin and inhibits hepatocellular carcinoma. Gastroenterology 2010, 139, 1762-1773. [CrossRef]

231. Sharma, D.; Wang, J.; Fu, P.P.; Sharma, S.; Nagalingam, A.; Mells, J.; Handy, J.; Page, A.J.; Cohen, C.; Anania, F.A.; et al. Adiponectin antagonizes the oncogenic actions of leptin in hepatocellular carcinogenesis. Hepatology 2010, 52, $1713-1722$. [CrossRef] [PubMed]

232. Kelesidis, T.; Kelesidis, I.; Chou, S.; Mantzoros, C.S. Narrative review: The role of leptin in human physiology: Emerging clinical applications. Ann. Intern. Med. 2010, 152, 93-100. [CrossRef] [PubMed]

233. Unger, R.H. Lipotoxic diseases. Annu. Rev. Med. 2002, 53, 319-336. [CrossRef] [PubMed]

234. Ikejima, K.; Honda, H.; Yoshikawa, M.; Hirose, M.; Kitamura, T.; Takei, Y.; Sato, N. Leptin augments inflammatory and profibrogenic responses in the murine liver induced by hepatotoxic chemicals. Hepatology 2001, 34, 288-297. [CrossRef]

235. Chitturi, S.; Farrell, G.; Frost, L.; Kriketos, A.; Lin, R.; Fung, C.; Liddle, C.; Samarasinghe, D.; George, J. Serum leptin in NASH correlates with hepatic steatosis but not fibrosis: A manifestation of lipotoxicity? Hepatology 2002, 36, 403-409. [CrossRef] [PubMed]

236. Polyzos, S.A.; Aronis, K.N.; Kountouras, J.; Raptis, D.D.; Vasiloglou, M.F.; Mantzoros, C.S. Circulating leptin in non-alcoholic fatty liver disease: A systematic review and meta-analysis. Diabetologia 2016, 59, 30-43. [CrossRef] [PubMed]

237. Chalasani, N.; Crabb, D.W.; Cummings, O.W.; Kwo, P.Y.; Asghar, A.; Pandya, P.K.; Considine, R.V. Does leptin play a role in the pathogenesis of human nonalcoholic steatohepatitis? Am. J. Gastroenterol. 2003, 98, 2771-2776. [CrossRef] [PubMed]

238. Angulo, P.; Alba, L.M.; Petrovic, L.M.; Adams, L.A.; Lindor, K.D.; Jensen, M.D. Leptin, insulin resistance, and liver fibrosis in human nonalcoholic fatty liver disease. J. Hepatol. 2004, 41, 943-949. [CrossRef] [PubMed]

239. Muse, E.D.; Obici, S.; Bhanot, S.; Monia, B.P.; McKay, R.A.; Rajala, M.W.; Scherer, P.E.; Rossetti, L. Role of resistin in diet-induced hepatic insulin resistance. J. Clin. Investig. 2004, 114, 232-239. [CrossRef] [PubMed]

240. Rangwala, S.M.; Rich, A.S.; Rhoades, B.; Shapiro, J.S.; Obici, S.; Rossetti, L.; Lazar, M.A. Abnormal glucose homeostasis due to chronic hyperresistinemia. Diabetes 2004, 53, 1937-1941. [CrossRef]

241. Bertolani, C.; Sancho-Bru, P.; Failli, P.; Bataller, R.; Aleffi, S.; DeFranco, R.; Mazzinghi, B.; Romagnani, P.; Milani, S.; Ginés, P.; et al. Resistin as an intrahepatic cytokine: Overexpression during chronic injury and induction of proinflammatory actions in hepatic stellate cells. Am. J. Pathol. 2006, 169, 2042-2053. [CrossRef] [PubMed]

242. Aller, R.; de Luis, D.A.; Fernandez, L.; Calle, F.; Velayos, B.; Olcoz, J.L.; Izaola, O.; Sagrado, M.G.; Conde, R.; Gonzalez, J.M. Influence of insulin resistance and adipokines in the grade of steatosis of nonalcoholic fatty liver disease. Dig. Dis. Sci. 2008, 53, 1088-1092. [CrossRef] 
243. Jamali, R.; Razavizade, M.; Arj, A.; Aarabi, M.H. Serum adipokines might predict liver histology findings in non-alcoholic fatty liver disease. World J. Gastroenterol. 2016, 22, 5096-5103. [CrossRef] [PubMed]

244. Rasouli, N.; Yao-Borengasser, A.; Miles, L.M.; Elbein, S.C.; Kern, P.A. Increased plasma adiponectin in response to pioglitazone does not result from increased gene expression. Am. J. Physiol. Endocrinol. Metab. 2006, 290, E42-E46. [CrossRef] [PubMed]

245. Delporte, C. Structure and physiological actions of ghrelin. Scientifica 2013, 2013, 518909. [CrossRef] [PubMed]

246. Marchesini, G.; Pagotto, U.; Bugianesi, E.; De Iasio, R.; Manini, R.; Vanni, E.; Pasquali, R.; Melchionda, N.; Rizzetto, M. Low ghrelin concentrations in nonalcoholic fatty liver disease are related to insulin resistance. J. Clin. Endocrinol. Metab. 2003, 88, 5674-5679. [CrossRef] [PubMed]

247. Purnell, J.Q.; Weigle, D.S.; Breen, P.; Cummings, D.E. Ghrelin levels correlate with insulin levels, insulin resistance, and highdensity lipoprotein cholesterol, but not with gender, menopausal status, or cortisol levels in humans. J. Clin. Endocrinol. Metab. 2003, 88, 5747-5752. [CrossRef] [PubMed]

248. Mao, Y.; Cheng, J.; Yu, F.; Li, H.; Guo, C.; Fan, X. Ghrelin Attenuated Lipotoxicity via Autophagy Induction and Nuclear Factor-кB Inhibition. Cell Physiol. Biochem. 2015, 37, 563-576. [CrossRef] [PubMed]

249. Schnyder, S.; Handschin, C. Skeletal muscle as an endocrine organ: PGC-1 $\alpha$, myokines and exercise. Bone 2015, 80, 115-125. [CrossRef]

250. Zhang, Y.; Li, R.; Meng, Y.; Li, S.; Donelan, W.; Zhao, Y.; Qi, L.; Zhang, M.; Wang, X.; Cui, T.; et al. Irisin stimulates browning of white adipocytes through mitogen-activated protein kinase p38 MAP kinase and ERK MAP kinase signaling. Diabetes 2014, 63, 514-525. [CrossRef] [PubMed]

251. Polyzos, S.A.; Mathew, H.; Mantzoros, C.S. Irisin: A true, circulating hormone. Metabolism 2015, 64, 1611-1618. [CrossRef] [PubMed]

252. Pérez-Sotelo, D.; Roca-Rivada, A.; Baamonde, I.; Baltar, J.; Castro, A.I.; Domínguez, E.; Collado, M.; Casanueva, F.F.; Pardo, M. Lack of Adipocyte-Fndc5/Irisin Expression and Secretion Reduces Thermogenesis and Enhances Adipogenesis. Sci. Rep. 2017, 7, 16289. [CrossRef]

253. Berndt, J.; Klöting, N.; Kralisch, S.; Kovacs, P.; Fasshauer, M.; Schön, M.R.; Stumvoll, M.; Blüher, M. Plasma visfatin concentrations and fat depot-specific mRNA expression in humans. Diabetes 2005, 54, 2911-2916. [CrossRef] [PubMed]

254. Chen, M.P.; Chung, F.M.; Chang, D.M.; Tsai, J.C.; Huang, H.F.; Shin, S.J.; Lee, Y.J. Elevated plasma level of visfatin/pre-B cell colony-enhancing factor in patients with type 2 diabetes mellitus. J. Clin. Endocrinol. Metab. 2006, 91, 295-299. [CrossRef] [PubMed]

255. Mousavi, Z.; Ganji, A.; Farrokh Tehrani, D.; Bahari, A.; EsmaeilZadeh, A.; Delghandi, M. Correlation of visfatin level with non-alcoholic fatty liver in metabolic syndrome. Med. J. Islam. Repub. Iran 2017, 31, 28. [CrossRef]

256. Erdem, G.; Dogru, T.; Tasci, I.; Bozoglu, E.; Muhsiroglu, O.; Tapan, S.; Ercin, C.N.; Sonmez, A. The effects of pioglitazone and metformin on plasma visfatin levels in patients with treatment naive type 2 diabetes mellitus. Diabetes Res. Clin. Pract. 2008, 82, 214-218. [CrossRef] [PubMed]

257. Kadoglou, N.P.; Tsanikidis, H.; Kapelouzou, A.; Vrabas, I.; Vitta, I.; Karayannacos, P.E.; Liapis, C.D.; Sailer, N. Effects of rosiglitazone and metformin treatment on apelin, visfatin, and ghrelin levels in patients with type 2 diabetes mellitus. Metabolism 2010, 59, 373-379. [CrossRef]

258. Kim, E.; Viatour, P. Hepatocellular carcinoma: Old friends and new tricks. Exp. Mol. Med. 2020, 52, 1898-1907. [CrossRef] [PubMed]

259. Cholankeril, G.; Patel, R.; Khurana, S.; Satapathy, S.K. Hepatocellular carcinoma in non-alcoholic steatohepatitis: Current knowledge and implications for managemen. World J. Hepatol. 2017, 9, 533-543. [CrossRef]

260. Wong, R.J.; Cheung, R.; Ahmed, A. Nonalcoholic steatohepatitis is the most rapidly growing indication for liver transplantation in patients with hepatocellular carcinoma in the U.S. Hepatology 2014, 59, 2188-2195. [CrossRef]

261. Jing, Y.Y.; Han, Z.P.; Sun, K.; Zhang, S.S.; Hou, J.; Liu, Y.; Li, R.; Gao, L.; Zhao, X.; Zhao, Q.D.; et al. Toll-like receptor 4 signaling promotes epithelial-mesenchymal transition in human hepatocellular carcinoma induced by lipopolysaccharide. BMC Med. 2012, 10, 98. [CrossRef] [PubMed]

262. Li, H.; Li, Y.; Liu, D.; Liu, J. LPS promotes epithelial-mesenchymal transition and activation of TLR4/JNK signaling. Tumour Biol. 2014, 35, 10429-10435. [CrossRef] [PubMed]

263. Gupta, H.; Youn, G.S.; Shin, M.J.; Suk, K.T. Role of Gut Microbiota in Hepatocarcinogenesis. Microorganisms $2019,7,121$. [CrossRef] [PubMed]

264. Al-Gayyar, M.M.; Abbas, A.; Hamdan, A.M. Chemopreventive and hepatoprotective roles of adiponectin (SULF2 inhibitor) in hepatocelluar carcinoma. Biol. Chem. 2016, 397, 257-267. [CrossRef] [PubMed]

265. Kamada, Y.; Matsumoto, H.; Tamura, S.; Fukushima, J.; Kiso, S.; Fukui, K.; Igura, T.; Maeda, N.; Kihara, S.; Funahashi, T.; et al. Hypoadiponectinemia accelerates hepatic tumor formation in a nonalcoholic steatohepatitis mouse model. J. Hepatol. 2007, 47, 556-564. [CrossRef] [PubMed]

266. Shen, J.; Yeh, C.C.; Wang, Q.; Gurvich, I.; Siegel, A.B.; Santella, R.M. Plasma Adiponectin and Hepatocellular Carcinoma Survival Among Patients Without Liver Transplantation. Anticancer Res. 2016, 36, 5307-5314. [CrossRef]

267. Siegel, A.B.; Goyal, A.; Salomao, M.; Wang, S.; Lee, V.; Hsu, C.; Rodriguez, R.; Hershman, D.L.; Brown, R.S., Jr.; Neugut, A.I.; et al. Serum adiponectin is associated with worsened overall survival in a prospective cohort of hepatocellular carcinoma patients. Oncology 2015, 88, 57-68. [CrossRef] [PubMed] 
268. Wei, R.; Hu, Y.; Dong, F.; Xu, X.; Hu, A.; Gao, G. Hepatoma cell-derived leptin downregulates the immunosuppressive function of regulatory T-cells to enhance the anti-tumor activity of CD8+ T-cells. Immunol. Cell Biol. 2016, 94, 388-399. [CrossRef]

269. Stefanou, N.; Papanikolaou, V.; Furukawa, Y.; Nakamura, Y.; Tsezou, A. Leptin as a critical regulator of hepatocellular carcinoma development through modulation of human telomerase reverse transcriptase. BMC Cancer 2010, 10, 442. [CrossRef] [PubMed]

270. Takakura, K.; Oikawa, T.; Nakano, M.; Saeki, C.; Torisu, Y.; Kajihara, M.; Saruta, M. Recent Insights into the Multiple Pathways Driving Non-alcoholic Steatohepatitis-Derived Hepatocellular Carcinoma. Front. Oncol. 2019, 9, 762. [CrossRef] [PubMed]

271. Léveillé, M.; Estall, J.L. Mitochondrial Dysfunction in the Transition from NASH to HCC. Metabolites 2019, 9, 233. [CrossRef] [PubMed]

272. Farrell, G.C.; van Rooyen, D. Liver cholesterol: Is it playing possum in NASH? Am. J. Physiol. Gastrointest. Liver Physiol. 2012, 303, G9-G11. [CrossRef]

273. Ioannou, G.N. The Role of Cholesterol in the Pathogenesis of NASH. Trends Endocrinol. Metab. 2016, 27, 84-95. [CrossRef]

274. Nakagawa, H.; Umemura, A.; Taniguchi, K.; Font-Burgada, J.; Dhar, D.; Ogata, H.; Zhong, Z.; Valasek, M.A.; Seki, E.; Hidalgo, J.; et al. ER stress cooperates with hypernutrition to trigger TNF-dependent spontaneous HCC development. Cancer Cell 2014, 26, 331-343. [CrossRef] [PubMed]

275. Stefan, N.; Häring, H.U. The role of hepatokines in metabolism. Nat. Rev. Endocrinol. 2013, 9, 144-152. [CrossRef] [PubMed]

276. von Loeffelholz, C.; Horn, P.; Birkenfeld, A.L.; Claus, R.A.; Metzing, B.U.; Döcke, S.; Jahreis, G.; Heller, R.; Hoppe, S.; Stockmann, M.; et al. Fetuin A is a Predictor of Liver Fat in Preoperative Patients with Nonalcoholic Fatty Liver Disease. J. Investig. Surg. 2016, 29, 266-274. [CrossRef] [PubMed]

277. Peter, A.; Kovarova, M.; Staiger, H.; Machann, J.; Schick, F.; Königsrainer, A.; Königsrainer, I.; Schleicher, E.; Fritsche, A.; Häring, H.-U.; et al. The hepatokines fetuin-A and fetuin-B are upregulated in the state of hepatic steatosis and may differently impact on glucose homeostasis in humans. Am. J. Physiol. Endocrinol. Metab. 2018, 314, E266-E273. [CrossRef] [PubMed]

278. Pal, D.; Dasgupta, S.; Kundu, R.; Maitra, S.; Das, G.; Mukhopadhyay, S.; Ray, S.; Majumdar, S.S.; Bhattacharya, S. Fetuin-A acts as an endogenous ligand of TLR4 to promote lipid-induced insulin resistance. Nat. Med. 2012, 18, 1279-1285. [CrossRef] [PubMed]

279. Stefan, N.; Hennige, A.M.; Staiger, H.; Machann, J.; Schick, F.; Kröber, S.M.; Machicao, F.; Fritsche, A.; Häring, H.-U. Alpha2Heremans-Schmid glycoprotein/fetuin-A is associated with insulin resistance and fat accumulation in the liver in humans. Diabetes Care 2006, 29, 853-857. [CrossRef]

280. Cui, Z.; Xuan, R.; Yang, Y. Serum fetuin A level is associated with nonalcoholic fatty liver disease in Chinese population. Oncotarget 2017, 8, 107149-107156. [CrossRef]

281. Kahraman, A.; Sowa, J.P.; Schlattjan, M.; Sydor, S.; Pronadl, M.; Wree, A.; Beilfuss, A.; Kilicarslan, A.; Altinbaş, A.; Bechmann, L.P.; et al. Fetuin-A mRNA expression is elevated in NASH compared with NAFL patients. Clin. Sci. 2013, 125, 391-400. [CrossRef]

282. Mukhuty, A.; Fouzder, C.; Mukherjee, S.; Malick, C.; Mukhopadhyay, S.; Bhattacharya, S.; Kundu, R. Palmitate induced Fetuin-A secretion from pancreatic $\beta$-cells adversely affects its function and elicits inflammation. Biochem. Biophys. Res. Commun. 2017, 491, 1118-1124. [CrossRef]

283. Lee, S.; Norheim, F.; Gulseth, H.L.; Langleite, T.M.; Kolnes, K.J.; Tangen, D.S.; Stadheim, H.K.; Gilfillan, G.D.; Holen, T.; Birkeland, K.I.; et al. Interaction between plasma fetuin-A and free fatty acids predicts changes in insulin sensitivity in response to long-term exercise. Physiol. Rep. 2017, 5, e13183. [CrossRef]

284. Dasgupta, S.; Bhattacharya, S.; Biswas, A.; Majumdar, S.S.; Mukhopadhyay, S.; Ray, S.; Bhattacharya, S. NF-kappaB mediates lipid-induced fetuin-A expression in hepatocytes that impairs adipocyte function effecting insulin resistance. Biochem. J. 2010, 429, 451-462. [CrossRef] [PubMed]

285. Mori, K.; Emoto, M.; Araki, T.; Yokoyama, H.; Lee, E.; Teramura, M.; Koyama, H.; Shoji, T.; Inaba, M.; Nishizawa, Y. Effects of pioglitazone on serum fetuin-A levels in patients with type 2 diabetes mellitus. Metabolism 2008, 57, 1248-1252. [CrossRef] [PubMed]

286. Ochi, A.; Mori, K.; Emoto, M.; Nakatani, S.; Morioka, T.; Motoyama, K.; Fukumoto, S.; Imanishi, Y.; Koyama, H.; Ishimura, E.; et al. Direct inhibitory effects of pioglitazone on hepatic fetuin-A expression. PLoS ONE 2014, 9, e88704. [CrossRef] [PubMed]

287. Li, L.; Gu, X.; Fang, M.; Ji, J.; Yi, C.; Gao, C. The diagnostic value of serum fucosylated fetuin A in hepatitis B virus-related liver diseases. Clin. Chem. Lab. Med. 2016, 54, 693-701. [CrossRef] [PubMed]

288. Aleksandrova, K.; Boeing, H.; Nöthlings, U.; Jenab, M.; Fedirko, V.; Kaaks, R.; Lukanova-McGregor, A.; Trichopoulou, A.; Trichopoulos, D.; Boffetta, P.; et al. Inflammatory and metabolic biomarkers and risk of liver and biliary tract cancer. Hepatology 2014, 60, 858-871. [CrossRef] [PubMed]

289. Pan, X.; Kaminga, A.C.; Chen, J.; Luo, M.; Luo, J. Fetuin-A and Fetuin-B in Non-Alcoholic Fatty Liver Disease: A Meta-Analysis and Meta-Regression. Int. J. Environ. Res. Public Health 2020, 17, 2735. [CrossRef]

290. Meex, R.C.; Hoy, A.J.; Morris, A.; Brown, R.D.; Lo, J.C.; Burke, M.; Goode, R.J.; Kingwell, B.A.; Kraakman, M.J.; Febbraio, M.A.; et al. Fetuin B Is a Secreted Hepatocyte Factor Linking Steatosis to Impaired Glucose Metabolism. Cell Metab. 2015, 22, 1078-1089. [CrossRef] [PubMed]

291. Zhou, W.; Yang, J.; Zhu, J.; Wang, Y.; Wu, Y.; Xu, L.; Yang, Y. Fetuin B aggravates liver X receptor-mediated hepatic steatosis through AMPK in HepG2 cells and mice. Am. J. Transl. Res. 2019, 11, 1498-1509.

292. Sato, M.; Kamada, Y.; Takeda, Y.; Kida, S.; Ohara, Y.; Fujii, H.; Akita, M.; Mizutani, K.; Yoshida, Y.; Yamada, M.; et al. Fetuin-A negatively correlates with liver and vascular fibrosis in nonalcoholic fatty liver disease subjects. Liver Int. 2015, 35, 925-935. [CrossRef] 
293. Ebert, T.; Linder, N.; Schaudinn, A.; Busse, H.; Berger, J.; Lichtinghagen, R.; Keim, V.; Wiegand, J.; Karlas, T. Association of fetuin $\mathrm{B}$ with markers of liver fibrosis in nonalcoholic fatty liver disease. Endocrine 2017, 58, 246-252. [CrossRef] [PubMed]

294. Saeed, A.; Dullaart, R.P.F.; Schreuder, T.C.M.A.; Blokzijl, H.; Faber, K.N. Disturbed Vitamin A Metabolism in Non-Alcoholic Fatty Liver Disease (NAFLD). Nutrients 2017, 10, 29. [CrossRef] [PubMed]

295. Zhong, G.; Kirkwood, J.; Won, K.J.; Tjota, N.; Jeong, H.; Isoherranen, N. Characterization of Vitamin A Metabolome in Human Livers With and Without Nonalcoholic Fatty Liver Disease. J. Pharmacol. Exp. Ther. 2019, 370, 92-103. [CrossRef] [PubMed]

296. Perduca, M.; Nicolis, S.; Mannucci, B.; Galliano, M.; Monaco, H.L. Human plasma retinol-binding protein (RBP4) is also a fatty acid-binding protein. Biochim. Biophys. Acta Mol. Cell Biol. Lipids 2018, 1863, 458-466. [CrossRef]

297. Alkhouri, N.; Lopez, R.; Berk, M.; Feldstein, A.E. Serum retinol-binding protein 4 levels in patients with nonalcoholic fatty liver disease. J. Clin. Gastroenterol. 2009, 43, 985-989. [CrossRef]

298. Wang, X.; Chen, X.; Zhang, H.; Pang, J.; Lin, J.; Xu, X.; Yang, L.; Ma, J.; Ling, W.; Chen, Y. Circulating retinol-binding protein 4 is associated with the development and regression of non-alcoholic fatty liver disease. Diabetes Metab. 2020, 46, 119-128. [CrossRef] [PubMed]

299. Seo, J.A.; Kim, N.H.; Park, S.Y.; Kim, H.Y.; Ryu, O.H.; Lee, K.W.; Lee, J.; Kim, D.L.; Choi, K.M.; Baik, S.H.; et al. Serum retinol-binding protein 4 levels are elevated in non-alcoholic fatty liver disease. Clin. Endocrinol. 2008, 68, 555-560. [CrossRef] [PubMed]

300. Graham, T.E.; Yang, Q.; Blüher, M.; Hammarstedt, A.; Ciaraldi, T.P.; Henry, R.R.; Wason, C.J.; Oberbach, A.; Jansson, P.A.; Smith, U.; et al. Retinol-binding protein 4 and insulin resistance in lean, obese, and diabetic subjects. N. Engl. J. Med. 2006, 354, $2552-2563$. [CrossRef] [PubMed]

301. Yang, Q.; Graham, T.E.; Mody, N.; Preitner, F.; Peroni, O.D.; Zabolotny, J.M.; Kotani, K.; Quadro, L.; Kahn, B.B. Serum retinol binding protein 4 contributes to insulin resistance in obesity and type 2 diabetes. Nature 2005, 436, 356-362. [CrossRef] [PubMed]

302. Petta, S.; Tripodo, C.; Grimaudo, S.; Cabibi, D.; Cammà, C.; Di Cristina, A.; Di Marco, V.; Di Vita, G.; Ingrao, S.; Mazzola, A.; et al. High liver RBP4 protein content is associated with histological features in patients with genotype 1 chronic hepatitis $C$ and with nonalcoholic steatohepatitis. Dig. Liver Dis. 2011, 43, 404-410. [CrossRef] [PubMed]

303. Bahr, M.J.; Boeker, K.H.; Manns, M.P.; Tietge, U.J. Decreased hepatic RBP4 secretion is correlated with reduced hepatic glucose production but is not associated with insulin resistance in patients with liver cirrhosis. Clin. Endocrinol. 2009, 70, 60-65. [CrossRef] [PubMed]

304. Hara, H.; Uchida, S.; Yoshimura, H.; Aoki, M.; Toyoda, Y.; Sakai, Y.; Morimoto, S.; Fukamachi, H.; Shiokawa, K.; Hanada, K. Isolation and characterization of a novel liver-specific gene, hepassocin, upregulated during liver regeneration. Biochim. Biophys. Acta 2000, 1492, 31-44. [CrossRef]

305. Abdelmoemen, G.; Khodeir, S.A.; Zaki, A.N.; Kassab, M.; Abou-Saif, S.; Abd-Elsalam, S. Overexpression of Hepassocin in Diabetic Patients with Nonalcoholic Fatty Liver Disease May Facilitate Increased Hepatic Lipid Accumulation. Endocr. Metab. Immune Disord. Drug Targets 2019, 19, 185-188. [CrossRef] [PubMed]

306. Wu, H.T.; Lu, F.H.; Ou, H.Y.; Su, Y.C.; Hung, H.C.; Wu, J.S.; Yang, Y.C.; Wu, C.L.; Chang, C.J. The role of hepassocin in the development of non-alcoholic fatty liver disease. J. Hepatol. 2013, 59, 1065-1072. [CrossRef]

307. Wu, H.T.; Ou, H.Y.; Hung, H.C.; Su, Y.C.; Lu, F.H.; Wu, J.S.; Yang, Y.C.; Wu, C.L.; Chang, C.J. A novel hepatokine, HFREP1, plays a crucial role in the development of insulin resistance and type 2 diabetes. Diabetologia 2016, 59, 1732-1742. [CrossRef]

308. Demchev, V.; Malana, G.; Vangala, D.; Stoll, J.; Desai, A.; Kang, H.W.; Li, Y.; Nayeb-Hashemi, H.; Niepel, M.; Cohen, D.E.; et al. Targeted deletion of fibrinogen like protein 1 reveals a novel role in energy substrate utilization. PLoS ONE 2013, 8, e58084. [CrossRef]

309. Cheng, K.P.; Ou, H.Y.; Hung, H.C.; Li, C.H.; Fan, K.C.; Wu, J.S.; Wu, H.T.; Chang, C.J. Unsaturated Fatty Acids Increase the Expression of Hepassocin through a Signal Transducer and Activator of Transcription 3-Dependent Pathway in HepG2 Cells. Lipids 2018, 53, 863-869. [CrossRef]

310. Jung, T.W.; Chung, Y.H.; Kim, H.C.; Abd El-Aty, A.M.; Jeong, J.H. Hyperlipidemia-induced hepassocin in the liver contributes to insulin resistance in skeletal muscle. Mol. Cell Endocrinol. 2018, 470, 26-33. [CrossRef]

311. Yu, H.T.; Yu, M.; Li, C.Y.; Zhan, Y.Q.; Xu, W.X.; Li, Y.H.; Li, W.; Wang, Z.D.; Ge, C.H.; Yang, X.M. Specific expression and regulation of hepassocin in the liver and down-regulation of the correlation of HNF1alpha with decreased levels of hepassocin in human hepatocellular carcinoma. J. Biol. Chem. 2009, 284, 13335-13347. [CrossRef] [PubMed]

312. Li, C.Y.; Cao, C.Z.; Xu, W.X.; Cao, M.M.; Yang, F.; Dong, L.; Yu, M.; Zhan, Y.Q.; Gao, Y.B.; Li, W.; et al. Recombinant human hepassocin stimulates proliferation of hepatocytes in vivo and improves survival in rats with fulminant hepatic failure. Gut 2010, 59, 817-826. [CrossRef] [PubMed]

313. Yan, J.; Yu, Y.; Wang, N.; Chang, Y.; Ying, H.; Liu, W.; He, J.; Li, S.; Jiang, W.; Li, Y.; et al. LFIRE-1/HFREP-1, a liver-specific gene, is frequently downregulated and has growth suppressor activity in hepatocellular carcinoma. Oncogene 2004, 230, 1939-1949. [CrossRef] [PubMed]

314. Kurosu, H.; Choi, M.; Ogawa, Y.; Dickson, A.S.; Goetz, R.; Eliseenkova, A.V.; Mohammadi, M.; Rosenblatt, K.P.; Kliewer, S.A.; Kuro, M.O. Tissue-specific expression of betaKlotho and fibroblast growth factor (FGF) receptor isoforms determines metabolic activity of FGF19 and FGF21. J. Biol. Chem. 2007, 282, 26687-26695. [CrossRef] [PubMed] 
315. Pan, J.; Parlee, S.D.; Brunel, F.M.; Li, P.; Lu, W.; Perez-Tilve, D.; Liu, F.; Finan, B.; Kharitonenkov, A.; DiMarchi, R.D. Optimization of Peptide Inhibitors of $\beta$-Klotho as Antagonists of Fibroblast Growth Factors 19 and 21. ACS Pharmacol. Transl. Sci. 2020, 3, 978-986. [CrossRef] [PubMed]

316. Wu, A.L.; Coulter, S.; Liddle, C.; Wong, A.; Eastham-Anderson, J.; French, D.M.; Peterson, A.S.; Sonoda, J. FGF19 regulates cell proliferation, glucose and bile acid metabolism via FGFR4-dependent and independent pathways. PLOS ONE 2011, 6, e17868. [CrossRef]

317. Bechmann, L.P.; Kocabayoglu, P.; Sowa, J.-P.; Sydor, S.; Best, J.; Schlattjan, M.; Beilfuss, A.; Schmitt, J.; Hannivoort, R.A.; Kilicarslan, A.; et al. Free fatty acids repress small heterodimer partner (SHP) activation and adiponectin counteracts bile acid-induced liver injury in superobese patients with nonalcoholic steatohepatitis. Hepatology 2013, 57, 1394-1406. [CrossRef] [PubMed]

318. Jiao, N.; Baker, S.S.; Chapa-Rodriguez, A.; Liu, W.; Nugent, C.A.; Tsompana, M.; Mastrandrea, L.; Buck, M.J.; Baker, R.D.; Genco, R.J.; et al. Suppressed hepatic bile acid signalling despite elevated production of primary and secondary bile acids in NAFLD. Gut 2018, 67, 1881-1891. [CrossRef] [PubMed]

319. Hyeon, J.; Ahn, S.; Lee, J.J.; Song, D.H.; Park, C.K. Expression of fibroblast growth factor 19 is associated with recurrence and poor prognosis of hepatocellular carcinoma. Dig. Dis. Sci. 2013, 58, 1916-1922. [CrossRef]

320. Li, Y.; Zhang, W.; Doughtie, A.; Cui, G.; Li, X.; Pandit, H.; Yang, Y.; Li, S.; Martin, R. Up-regulation of fibroblast growth factor 19 and its receptor associates with progression from fatty liver to hepatocellular carcinoma. Oncotarget 2016, 7, 52329-52339. [CrossRef]

321. Miura, S.; Mitsuhashi, N.; Shimizu, H.; Kimura, F.; Yoshidome, H.; Otsuka, M.; Kato, A.; Shida, T.; Okamura, D.; Miyazaki, M. Fibroblast growth factor 19 expression correlates with tumor progression and poorer prognosis of hepatocellular carcinoma. BMC Cancer 2012, 12, 56. [CrossRef]

322. Chen, L.; Liu, H.; Liu, J.; Zhu, Y.; Xu, L.; He, H.; Zhang, H.; Wang, S.; Wu, Q.; Liu, W.; et al. Klotho endows hepatoma cells with resistance to anoikis via VEGFR2/PAK1 activation in hepatocellular carcinoma. PLoS ONE 2013, 8, e58413. [CrossRef] [PubMed]

323. Coskun, T.; Bina, H.A.; Schneider, M.A.; Dunbar, J.D.; Hu, C.C.; Chen, Y.; Moller, D.E.; Kharitonenkov, A. Fibroblast growth factor 21 corrects obesity in mice. Endocrinology 2008, 149, 6018-6027. [CrossRef] [PubMed]

324. Xu, J.; Lloyd, D.J.; Hale, C.; Stanislaus, S.; Chen, M.; Sivits, G.; Vonderfecht, S.; Hecht, R.; Li, Y.S.; Lindberg, R.A.; et al. Fibroblast growth factor 21 reverses hepatic steatosis, increases energy expenditure, and improves insulin sensitivity in diet-induced obese mice. Diabetes 2009, 58, 250-259. [CrossRef] [PubMed]

325. Gong, Q.; Hu, Z.; Zhang, F.; Cui, A.; Chen, X.; Jiang, H.; Gao, J.; Chen, X.; Han, Y.; Liang, Q.; et al. Fibroblast growth factor 21 improves hepatic insulin sensitivity by inhibiting mammalian target of rapamycin complex 1 in mice. Hepatology 2016, 64, 425-438. [CrossRef] [PubMed]

326. Zhang, X.; Yeung, D.C.; Karpisek, M.; Stejskal, D.; Zhou, Z.G.; Liu, F.; Wong, R.L.; Chow, W.S.; Tso, A.W.; Lam, K.S.; et al. Serum FGF21 levels are increased in obesity and are independently associated with the metabolic syndrome in humans. Diabetes 2008, 57, 1246-1253. [CrossRef] [PubMed]

327. Li, H.; Fang, Q.; Gao, F.; Fan, J.; Zhou, J.; Wang, X.; Zhang, H.; Pan, X.; Bao, Y.; Xiang, K.; et al. Fibroblast growth factor 21 levels are increased in nonalcoholic fatty liver disease patients and are correlated with hepatic triglyceride. J. Hepatol. 2010, 53, 934-940. [CrossRef]

328. Hong, E.S.; Lim, C.; Choi, H.Y.; Lee, Y.K.; Ku, E.J.; Moon, J.H.; Park, K.S.; Jang, H.C.; Choi, S.H. Plasma fibroblast growth factor 21 levels increase with ectopic fat accumulation and its receptor levels are decreased in the visceral fat of patients with type 2 diabetes. BMJ Open Diabetes Res. Care 2019, 7, e000776. [CrossRef]

329. Baek, J.; Nam, H.K.; Rhie, Y.J.; Lee, K.H. Serum FGF21 Levels in Obese Korean Children and Adolescents. J. Obes. Metab. Syndr. 2017, 26, 204-209. [CrossRef]

330. Flisiak-Jackiewicz, M.; Bobrus-Chociej, A.; Wasilewska, N.; Tarasow, E.; Wojtkowska, M.; Lebensztejn, D.M. Can hepatokines be regarded as novel non-invasive serum biomarkers of intrahepatic lipid content in obese children? Adv. Med. Sci. 2019, 64, 280-284. [CrossRef]

331. Rusli, F.; Deelen, J.; Andriyani, E.; Boekschoten, M.V.; Lute, C.; van den Akker, E.B.; Müller, M.; Beekman, M.; Steegenga, W.T. Fibroblast growth factor 21 reflects liver fat accumulation and dysregulation of signalling pathways in the liver of C57BL/6J mice. Sci. Rep. 2016, 6, 30484. [CrossRef]

332. Yan, H.; Xia, M.; Chang, X.; Xu, Q.; Bian, H.; Zeng, M.; Rao, S.; Yao, X.; Tu, Y.; Jia, W.; et al. Circulating fibroblast growth factor 21 levels are closely associated with hepatic fat content: A cross-sectional study. PLoS ONE 2011, 6, e24895. [CrossRef] [PubMed]

333. Yang, M.; Xu, D.; Liu, Y.; Guo, X.; Li, W.; Guo, C.; Zhang, H.; Gao, Y.; Mao, Y.; Zhao, J. Combined Serum Biomarkers in Non-Invasive Diagnosis of Non-Alcoholic Steatohepatitis. PLoS ONE 2015, 10, e0131664. [CrossRef]

334. Yang, C.; Lu, W.; Lin, T.; You, P.; Ye, M.; Huang, Y.; Jiang, X.; Wang, C.; Wang, F.; Lee, M.-H.; et al. Activation of Liver FGF21 in hepatocarcinogenesis and during hepatic stress. BMC Gastroenterol. 2013, 13, 67. [CrossRef]

335. Kong, F.J.; Ma, L.L.; Li, G.; Chen, Y.X.; Zhou, J.Q. Circulating Betatrophin Levels and Gestational Diabetes Mellitus: A Systematic Review and Meta-Analysis. PLoS ONE 2017, 12, e0169941. [CrossRef]

336. von Loeffelholz, C.; Pfeiffer, A.F.H.; Lock, J.F.; Lieske, S.; Döcke, S.; Murahovschi, V.; Kriebel, J.; de Las Heras Gala, T.; Grallert, H.; Rudovich, N.R.; et al. ANGPTL8 (Betatrophin) is Expressed in Visceral Adipose Tissue and Relates to Human Hepatic Steatosis in Two Independent Clinical Collectives. Horm. Metab. Res. 2017, 49, 343-349. [CrossRef] [PubMed] 
337. Lee, Y.H.; Lee, S.G.; Lee, C.J.; Kim, S.H.; Song, Y.M.; Yoon, M.R.; Jeon, B.H.; Lee, J.H.; Lee, B.W.; Kang, E.S.; et al. Association between betatrophin/ANGPTL8 and non-alcoholic fatty liver disease: Animal and human studies. Sci. Rep. 2016, 6, 24013. [CrossRef] [PubMed]

338. Wang, C.; Tong, Y.; Wen, Y.; Cai, J.; Guo, H.; Huang, L.; Xu, M.; Feng, M.; Chen, X.; Zhang, J.; et al. Hepatocellular CarcinomaAssociated Protein TD26 Interacts and Enhances Sterol Regulatory Element-Binding Protein 1 Activity to Promote Tumor Cell Proliferation and Growth. Hepatology 2018, 68, 1833-1850. [CrossRef] [PubMed]

339. Zhang, R. The ANGPTL3-4-8 model, a molecular mechanism for triglyceride trafficking. Open Biol. 2016, 6, 150272. [CrossRef] [PubMed]

340. Kovrov, O.; Kristensen, K.K.; Larsson, E.; Ploug, M.; Olivecrona, G. On the mechanism of angiopoietin-like protein 8 for control of lipoprotein lipase activity. J. Lipid Res. 2019, 60, 783-793. [CrossRef] [PubMed]

341. Yin, Y.; Ding, X.; Peng, L.; Hou, Y.; Ling, Y.; Gu, M.; Wang, Y.; Peng, Y.; Sun, H. Increased Serum ANGPTL8 Concentrations in Patients with Prediabetes and Type 2 Diabetes. J. Diabetes Res. 2017, 2017, 8293207. [CrossRef]

342. Gusarova, V.; Alexa, C.A.; Na, E.; Stevis, P.E.; Xin, Y.; Bonner-Weir, S.; Cohen, J.C.; Hobbs, H.H.; Murphy, A.J.; Yancopoulos, G.D.; et al. ANGPTL8/betatrophin does not control pancreatic beta cell expansion. Cell 2014, 159, 691-696. [CrossRef]

343. Cox, A.R.; Lam, C.J.; Bonnyman, C.W.; Chavez, J.; Rios, J.S.; Kushner, J.A. Angiopoietin-like protein 8 (ANGPTL8)/betatrophin overexpression does not increase beta cell proliferation in mice. Diabetologia 2015, 58, 1523-1531. [CrossRef] [PubMed]

344. Zhang, L.; Shannon, C.E.; Bakewell, T.M.; Abdul-Ghani, M.A.; Fourcaudot, M.; Norton, L. Regulation of ANGPTL8 in liver and adipose tissue by nutritional and hormonal signals and its effect on glucose homeostasis in mice. Am. J. Physiol. Endocrinol. Metab. 2020, 318, E613-E624. [CrossRef]

345. Chen, Y.Q.; Pottanat, T.G.; Siegel, R.W.; Ehsani, M.; Qian, Y.W.; Zhen, E.Y.; Regmi, A.; Roell, W.C.; Guo, H.; Luo, M.J.; et al. Angiopoietin-like protein 8 differentially regulates ANGPTL3 and ANGPTL4 during postprandial partitioning of fatty acids. J. Lipid Res. 2020, 61, 1203-1220. [CrossRef] [PubMed]

346. Chi, X.; Britt, E.C.; Shows, H.W.; Hjelmaas, A.J.; Shetty, S.K.; Cushing, E.M.; Li, W.; Dou, A.; Zhang, R.; Davies, B.S.J. ANGPTL8 promotes the ability of ANGPTL3 to bind and inhibit lipoprotein lipase. Mol. Metab. 2017, 6, 1137-1149. [CrossRef] [PubMed]

347. Dijk, W.; Kersten, S. Regulation of lipid metabolism by angiopoietin-like proteins. Curr. Opin. Lipidol. 2016, $27,249-256$. [CrossRef] [PubMed]

348. Shimizugawa, T.; Ono, M.; Shimamura, M.; Yoshida, K.; Ando, Y.; Koishi, R.; Ueda, K.; Inaba, T.; Minekura, H.; Kohama, T.; et al. ANGPTL3 decreases very low density lipoprotein triglyceride clearance by inhibition of lipoprotein lipase. J. Biol. Chem. 2002, 277, 33742-33748. [CrossRef]

349. Yoshida, K.; Shimizugawa, T.; Ono, M.; Furukawa, H. Angiopoietin-like protein 4 is a potent hyperlipidemia-inducing factor in mice and inhibitor of lipoprotein lipase. J. Lipid Res. 2002, 43, 1770-1772. [CrossRef] [PubMed]

350. Ng, K.T.; Xu, A.; Cheng, Q.; Guo, D.Y.; Lim, Z.X.; Sun, C.K.; Fung, J.H.; Poon, R.T.; Fan, S.T.; Lo, C.M.; et al. Clinical relevance and therapeutic potential of angiopoietin-like protein 4 in hepatocellular carcinoma. Mol. Cancer 2014, 13, 196. [CrossRef] [PubMed] 